\title{
Mangroves, fishers, and the struggle for adaptive comanagement: applying the social-ecological systems framework to a marine extractive reserve (RESEX) in Brazil
}

\author{
$\underline{\text { Stefan Partelow }}^{1,2}$, Marion Glaser $^{1,3}, \underline{\text { Sofía Solano Arce }}^{1,4}$, Roberta Sá Leitão Barboza $^{5}$ and Achim Schlüter $^{1,2}$
}

ABSTRACT. Brazil has a network of marine extractive reserves (RESEX), a form of marine protected area (MPA) using comanagement. The RESEX program aims to bring traditionally marginalized populations with natural resource dependent livelihoods into national development processes by empowering them to participate in governance and steward biodiversity conservation. We apply the socialecological systems framework (SESF) and collective action theory to diagnose challenges for comanagement in the Caete-Teperacu marine RESEX near Bragança, Brazil, a multiuse mangrove estuary supporting a small-scale crab fishery. We conducted key informant interviews and build on over 20 years of research in the region to provide an overarching analysis of the challenges facing comanagement. We describe the variables from the SESF in the case context and find that many social and ecological variables interact in clusters over time, and these clusters can be identified as themes, including (1) social and political momentum supporting the RESEX; (2) shifting perceptions of local residents and fishers; (3) patron-client relationships and social-ecological traps; (4) challenges with institutional fit; and (5) the interactions between harvesting closures, compensation, and dependence on local natural resources. Furthermore, we use collective action theory to help explain the role that each variable plays in either hindering or enabling successful governance. Our findings suggest that institutional resilience is needed to make RESEX adaptive to shifting social and political momenta. It could do this by providing more platforms for communication, deliberation, and knowledge exchange among the relevant actors. We believe our findings reflect broader challenges facing RESEX implementation throughout Brazil, and lessons can be learned for MPAs facing difficulties with the implementation of comanagement worldwide.

Key Words: adaptive comanagement; coastal; collaborative governance; collective action; conservation; crabs; marine protected area; small-scale fisheries; social-ecological system

\section{INTRODUCTION}

Up until the last few years, social and political momentum continued to build in Brazil for the establishment of marine extractive reserves (marine RESEX), a form of marine protected area (MPA) aimed at democratizing access to natural resources through participatory comanagement with both social and environmental goals (ICMBio 2012, Santos and Brannstrom 2015). The RESEX program aims to bring marginalized traditional populations that depend on local natural resources into national development processes by empowering them to participate in national government supported formal management of RESEX areas. The RESEX goals include the sustainable management of resources to maintain local livelihoods while simultaneously stewarding biodiversity conservation (e.g., Simonian and Glaser 2002).

In Brazil, RESEX comanagement is a major advance because it legitimizes nature-dependent and largely marginalized natural resource users in a formal legal framework to replace widespread illegality in harvesting practice and to motivate collective action for sustainable resource use (Glaser et al. 2003, Di Ciommo 2007). Other types of conservation units along with RESEX are managed by the Chico Mendes Institute for Biodiversity Conservation (ICMBio) throughout Brazil. The ICMBio was founded in 2009 and is part of the Federal Ministry of the Environment (MMA). The ICMBio also collaborates with the
Institute of the Environment and Renewable Natural Resources (IBAMA), tasked with monitoring environmental laws.

Of Brazil's currently 88 RESEX, 24 are marine and 12 of these are located on the coast of the state of Pará, including the case study of this research. Marine RESEX programs have struggled for success (da Silva 2004, Santos and Schiavetti 2014), facing a variety of challenges including social conflicts between fishers and other actors (Santos and Schiavetti 2014), low social and cultural preparedness for formal governance (da Silva 2004, Di Ciommo 2007), low socioeconomic welfare and few alternative livelihood opportunities (Glaser and da Silva Oliveira 2004, Santos and Brannstrom 2015), and deficient monitoring and compliance with rules (Erler et al. 2015, Nobre et al. 2017). Recognition for the historical dynamics of local management and adjusting comanagement to local norms has shown to be difficult, and failure can hinder progress, which has been shown in other non-RESEX areas in Brazil (Tebet et al. 2018). Most studies see the RESEX program as a move in the right direction, but argue that implementation is affected by a multitude of institutional challenges.

The Brazilian RESEX program expresses a shift in the political discourse on environmental management toward a collaborative "people and nature" conservation model (Mace 2014, Bennett et al. 2017), reflecting a worldwide conceptual move toward collaborative governance through comanagement (Armitage et

\footnotetext{
${ }^{1}$ Leibniz Centre for Tropical Marine Research (ZMT), Bremen, Germany, ${ }^{2}$ Jacobs University, Bremen, Germany, ${ }^{3}$ University of Bremen, Germany, ${ }^{4}$ University of Costa Rica, ${ }^{5}$ ESAC (Grupo de Estudos Socioambientais Costeiros), Universidade Federal do Pará (UFPA)/Campus Bragança, Bragança, Brazil
} 
al. 2009, Bodin 2017). Comanagement brings multiple state and nonstate actors together to cooperate, typically including local resource users (e.g., fishers) and other civil society groups (e.g., NGOs, private sector; Carlsson and Berkes 2005).

All marine RESEX apply a generic comanagement model. However, this is not a panacea for success. To improve the likelihood of sustainable human-nature relations, comanagement requires adaptation to changing social-ecological system (SES) conditions and other contextual factors (Jentoft 2000, Béné and Neiland 2004, Folke et al. 2005, Ostrom and Cox 2010, Basurto and Nenadovic 2012). Adaptive comanagement, a flexible and long-term management approach including numerous stakeholders at various political levels who jointly make decisions (Ruitenbeek and Cartier 2001, Armitage et al. 2008), has been reported as more successful when the involved actors can create institutions for collaboration that facilitate mutual learning and knowledge integration specific to context. Recognizing the unique socialecological conditions of rural coastal Brazil and making policies like RESEX adaptive to the conditions of each case, is critical for success (Borges et al. 2017, da Rocha et al. 2017).

Collective action is a necessary part of comanagement (Noble 2000, Folke et al. 2005, Bodin 2017). Actors need to cooperate to develop mutually agreed upon rules, institutions, and goals. Collective action theories provide a useful lens to unpack the reasons why establishing institutions for cooperation is difficult. Many social and ecological characteristics have been shown to hinder or enable collective action over time (Ostrom 2009, Poteete et al. 2010, Bodin 2017). Much of the literature on MPA governance emphasizes the need to recognize how complex socialecological interactions influence governance. Synergies between commons, collective action, and SES research are improving our understanding of the enabling conditions for successful collaborative governance (Ostrom 2009, Bodin 2017).

At the land-sea interface, coastal SES research has helped unpack the complexity of spatially overlapping characteristics and interactions between marine and terrestrial systems, and how these influence sustainability (Alexander et al. 2016, Pittman and Armitage 2016, Partelow et al. 2018a). Coastal zones often have multiple spatially proximate ecosystem types, resource uses, and actors, often with divergent interests, creating challenges for collective management (Glaser and Glaeser 2012, Glaser et al. 2012, Schlüter et al. 2018). They face a double squeeze from both terrestrial and marine drivers of change. This emphasizes the need for knowledge integration across those systems and between those actors who use them to increase the adaptive capacity of governance (Álvarez-Romero et al. 2011, Whitney et al. 2017). Mangrove and estuarine systems demonstrate this complexity, because they are often subject to polices designed for land management and conservation that do not take into account the fluid dynamics of aquatic species or the specific resource-use behavior in small-scale fisheries.

We apply the social-ecological systems framework (SESF) using qualitative data (Ostrom 2009, McGinnis and Ostrom 2014) to diagnose the challenges facing comanagement in response to social-ecological change in the Caeté-Taperaçu (CT) RESEX. The CT RESEX is located near the city of Bragança, State of Pará, Brazil, 215 kilometers from its state capital Belem, on the mouth of the Amazon River delta (Fig. 1; Saint-Paul and
Schneider 2010). Bragança has 113,000 inhabitants, with more than 40,000 living in rural and largely undeveloped areas. The CT RESEX is a large coastal estuary forming a peninsula with numerous rivers and tributaries, and it is embedded in the world's second largest continuous mangrove ecosystem spanning 23,000 square kilometers.

Fig. 1. (A) Location of the Caeté-Taperaçú RESEX in Brazil. (B) Bragança area and the RESEX boundaries and zones within the RESEX according to the management plan. Source: (ICMBio 2012).

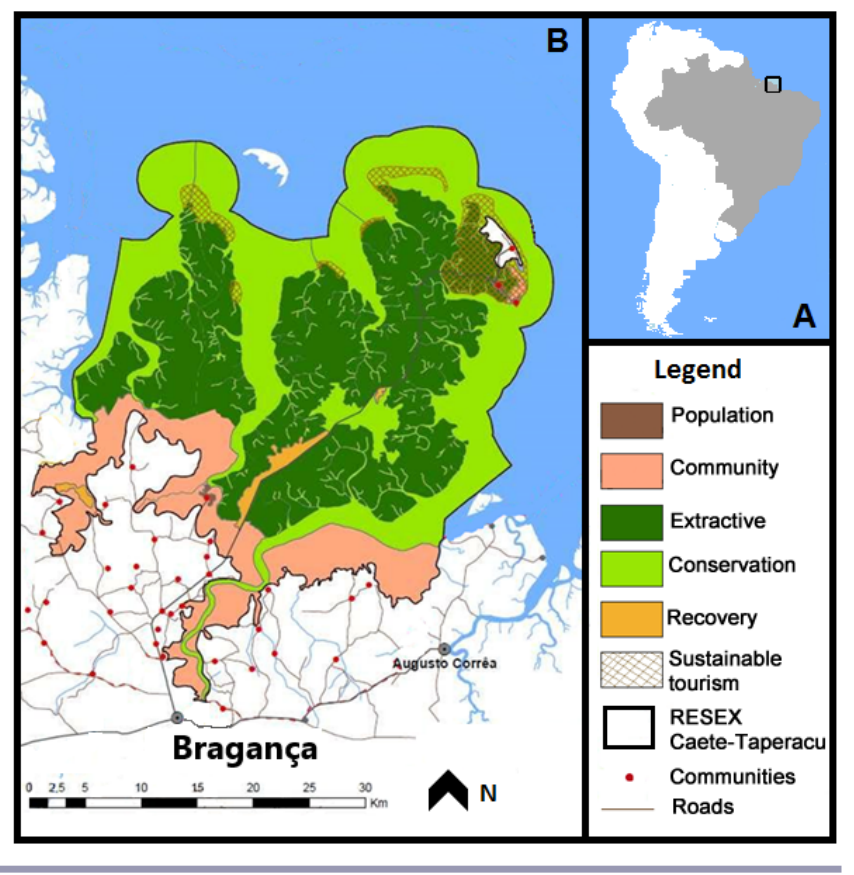

A number of studies have analyzed RESEX areas using Ostrom's (1990) design principles (da Silva 2004, Le Tourneau and Beaufort 2017, Nobre et al. 2017), and in similar non-RESEX areas (Tebet et al. 2018), but to our knowledge this study is the first to apply the SESF. The framework is well suited for the study of smallscale fisheries (Basurto et al. 2013, Partelow 2015) with numerous case study applications in the literature (Schlüter and Madrigal 2012, Ernst et al. 2013, Leslie et al. 2015, Partelow and Boda 2015, Torres Guevara et al. 2016). Few studies have demonstrated the value of the SESF as a tool for qualitative research as a coding framework for the organization and analysis of qualitative data (e.g., Ban et al. 2015, Hoogesteger 2015), particularly in smallscale fisheries and coastal systems (e.g., Lozano and Heinen 2016, London et al. 2017, Partelow et al. 2018b). Qualitative data analysis is an integral part of environmental social science research because it allows for thick descriptions of complex variables and the evolution of narratives and interactions over time in observational research (Bryman 2012, Cox 2015). Our study uses the SESF in two novel ways. We examine groups of interacting second-tier variables and their interactive effects as key interactions influencing overall outcomes. We also consider these interactions over time (two decades) in our analysis, which has only been explored by a few articles (Epstein et al. 2014, Ban et al. 2015). 


\section{METHODS}

This study conducts qualitative research (Silverman 2005, Flick 2014) using a diagnostic approach guided by the SESF (Ostrom 2007, Cox 2011, Hinkel et al. 2015, Partelow 2016). The SESF is a diagnostic tool structured into tiers of nested and related concepts (Appendix 1). The unit of analysis in this study, the focal SES, is the biophysical area within the political borders of the CT RESEX (Fig. 1) and the associated actors and registered residents, with focus on fishers harvesting mangrove crab (Ucides cordatus), the most economically important natural resource in the area (Glaser et al. 2010a). This study is guided by the following research questions (RQ):

1. What SESF variables are present and potentially influencing governance and collective outcomes in the CT RESEX?

2. What are the key interactions between the second-tier variables of the SESF in the CT RESEX?

3. With many separate research projects in the CT RESEX, how can an analysis of the SESF provide a synthesis and overview to inform more effective comanagement?

\section{Primary data}

Semistructured key informant interviews $(n=31)$ were conducted between March and July 2016 (Table 1). Recorded interviews lasted between 45 minutes and 2 hours. Individuals were selected for their direct experience with the formation and/or implementation of the RESEX. Snowball sampling allowed for finding other relevant individuals to interview. Multiple entry points into the social network of key informants were employed. Most interviewees had been involved with the RESEX for more than 10 years including researchers, board directors of the community associations, RESEX deliberative council members, ICMBio employees, Bragança municipality employees, community leaders, associated NGOs, and actors from the private sector. Interviews were conducted and recorded in Portuguese, then translated, transcribed, and analyzed by the authors.

\section{Secondary data}

Most of the data that supports our study comes from primary sources, but academic literature provided useful secondary data. This included local research that had resulted in Portuguese language publications from the Federal University of Pará (UFPA) in Bragança. Bragança was the location of a 10-year international research cooperation (the MADAM project) from 1995-2005 cofunded by the Brazilian and German research ministries, with a comprehensive book published on the many social and biophysical dimensions of the area pre-RESEX (SaintPaul and Schneider 2010). Many chapters of this book provided data, as well as six published theses from UFPA, four postRESEX evaluation reports, and the official RESEX management plan documents. Additional background literature was included as cited.

\section{Data analysis}

Interviews followed a diagnostic process, first developing and asking general questions related to the first-tier variables of the SESF. Based on the answers to these, and after each interview, the two authors who did the fieldwork (SS and SP) discussed and briefly analyzed responses. This allowed for refining and developing more nuanced questions related to specific second-tier variables for following interviews. The length of the interviews varied substantially because some informants had extensive knowledge on specific topics, and provided detailed information in relation to only a few or a series of related questions. Others provided general information on many questions. A structure of starting questions was tailored to each individual based on who they were and what they were likely to know about. Interview data was cross-checked with multiple interviewees. Once a point of saturation in responses to a question occurred (similar responses to a question from numerous individuals) the data on that variable was considered validated (Fusch and Ness 2015). Varied responses prompted further questions and cross-checking. Answers in the early stages of the research typically allowed for a descriptive understanding of variables, supporting RQ1. Later in the diagnostic process, responses to further refined questions provided data on interactions between variables and more complex system dynamics, supporting RQ2. The final synthesized description of each relevant SESF variable and its interactions in the SES are presented in the results.

Table 1. List of interviewees by stakeholder group, the specific actor within that group, and the number of interviews. ICMbio $=$ Chico Mendes Institute for Biodiversity Conservation; RESEX $=$ marine extractive reserve.

\begin{tabular}{llc}
\hline \hline Actor group & Who & $\begin{array}{c}\text { Number } \\
\text { of } \\
\text { interviews }\end{array}$ \\
\hline Government & ICMBio local manager & 2 \\
& ICMBio local employees & 3 \\
& Mayor of Bragança & 1 \\
& Municipal environmental office & 2 \\
RESEX Deliberative & Municipal fisheries department & 1 \\
Council & Deliberative council members & 6 \\
RESEX community & Current RESEX president & 1 \\
members & Ex-RESEX president & 1 \\
& $\begin{array}{l}\text { Community leaders (also } \\
\text { representatives) }\end{array}$ & 6 \\
Association of RESEX & Community representatives (only) & 3 \\
Users & Board of directors \\
Academic & (ASSUREMACATA) & 6 \\
NGO & Federal University of Pará & 4 \\
Private sector & Federal Institute of Pará & 1 \\
\hline & Pastoral Council of Fishermen \\
(CPP) & 4 \\
\hline
\end{tabular}

Primary qualitative data from interviews were transcribed and secondary data (i.e., articles, book chapters, theses) were entered into the qualitative data analysis software MaxQDA (VERBI Software 2016). In a first step, all data were coded using the SESF variables as a coding framework for qualitative content analysis (i.e., qualitative text segments were linked to the defined secondtier variables they provide data on). Next, one of three actions was taken. Either the data represented a consensus on the description and role of that variable, or conflicting accounts were identified, or further third-tier variables were developed to make a more nuanced description and analysis, following an ontological logic (Frey and Cox 2015). The two authors who conducted the fieldwork agreed on how the data was coded through consensus coding. After final coding, each second-tier variable was described in the context of the CT RESEX and analyzed with MaxQDA 
for its relation to other variables through jointly coded segments and interpretive analysis. Using the description of each secondtier variable in the case, collective action theories were used to analyze the role of each variable. This provided an additional explanatory lens to view the role each variable plays in relation to current outcomes related to collective action and comanagement.

\section{RESULTS}

Social, economic, and political settings $(S)$

With the end of the military era and the new Brazilian constitution in 1988, an era of political stability ensued from 1998 to 2015 with continuous investments into social and economic sectors, eradicating extreme poverty and expanding Brazil's lower middle class (S1). Recently, increasing political instability saw the impeachment of the last elected president while cuts in educational, environmental, and public service expenses have had negative implications for the incomes and livelihood chances of the poor (Pinheiro et al. 2015; S3). Exclusionary and often elitist transformations in agrarian, environmental, and indigenous policies have been shaping the current socio-political scenario, threatening the integrity of conservation initiatives and the people dependent on local natural resources.

North Brazilian economic development has been consistently well below national averages for many decades. Regional inequalities between North and South Brazil persist despite some recent successes in poverty eradication. A particular problem is the lack of access to higher education and to income options that are not based on traditional natural resource extraction such as fishing (S2). Expanding seafood markets in Brazil have turned the Bragança region into a national seafood supply center (S5) and even an international market for certain species, e.g., red snapper (Lutjanus purpureus) and acoupa weakfish (Cynoscion acoupa; the swim bladder is sun dried and sold to emulsifier industries and has a high value in export markets; Bentes et al. 2012). This is in part due to changes in technology (S7) for the processing of crabs (Ucides cordatus). However, this has led to the first signs of crab overexploitation, a key species of the ecosystem and regional economy (Glaser and Diele 2004, Koch and Nordhaus 2010). Global market processes are thus threatening the ability of local natural resource-dependent communities to achieve conservation and sustainability goals (Sant'ana-Júnior 2014).

\section{Resource system ( $R S$ )}

The CT RESEX coastal mangrove estuary has clear biophysical boundaries surrounding the small-scale mangrove crab fishery (RS1) between the Caeté and Taperaçú rivers on the Bragança Peninsula (RS2) covering over $420 \mathrm{~km}^{2}$ (RS3). Accessing the mangrove is challenging; it requires taking a public bus or bicycle along a public road or a boat into small estuarine canals, which are only accessible at high tide. However, actual crab collection is always done on foot, walking and wading through the mangrove area to find crab burrows located around tree roots. The mangrove forest is a swamp with entangled roots in deep thick mud and requires considerable physical endurance and local knowledge to navigate for fishing (Fig. 2; RS4). Due to the difficulties with carrying large sacks of crabs, fishers don't go far into the forest or stray off known routes (RS9; Thies-Albrecht 2016). Seasonality affects cycles of ecosystem functioning (RS7). The rainy season, from January to May, is more difficult and dangerous for fishing activities than the dry season from June to December.

Fig. 2. (A) A fisher harvesting mangrove crabs (Ucides cordatus) by hand. (B) Women processing cooked crabs in a privately owned facility. (C) Live mangrove crabs for sale in Bragança city market. (D) Fishing boats during low tide in the mangrove estuary. (All photos by authors).

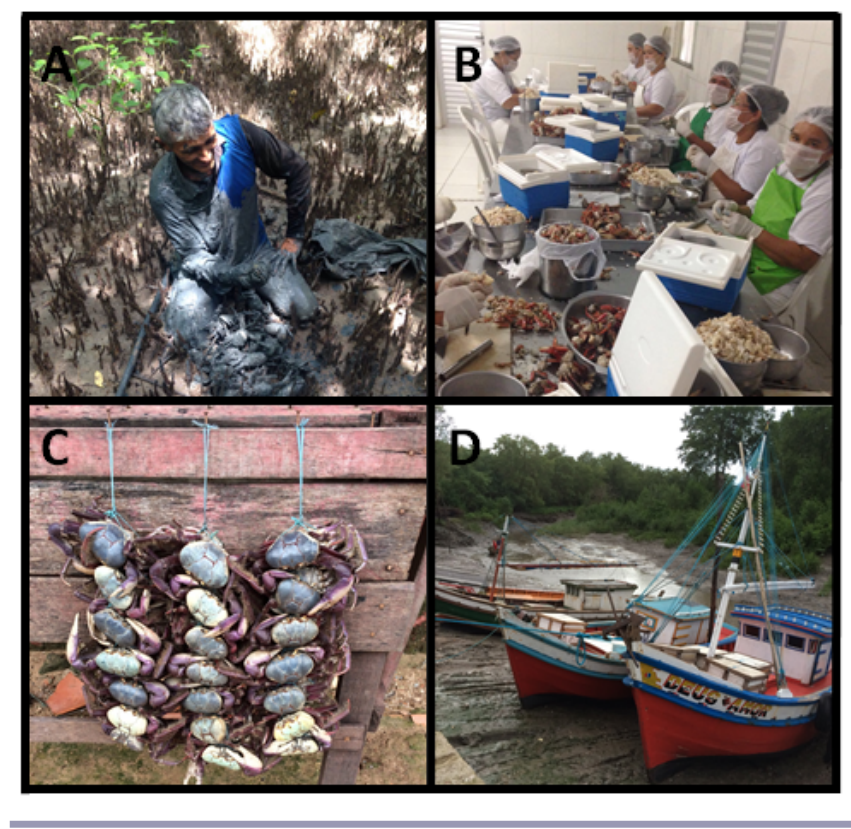

Resource units ( $R U$ )

Multiple resource units are harvested in the CT RESEX; more than 20 have been identified including mixed finfish species, crabs, and mangrove wood (Glaser et al. 2010a). This study focuses on the small-scale mangrove crab fishery for Ucides cordatus, the economically most important species. Second-tier variables can be applied to each resource unit (McGinnis and Ostrom 2014), but this reaches beyond our scope.

Mangrove crabs (Ucides cordatus) are hardly mobile in their adult lives, typically foraging within a one-meter radius of their burrow (RU1; Diele and Koch 2010). Crabs seem to only venture further out during the annual six days per month during January to March of the "andada" reproduction period. Mangrove crabs have a slow growth rate and reproduce during the rainy season peaking in January and February (RU2). Females carry eggs for three-four weeks before releasing them during spring tides after which they spread across the estuary as juveniles (RU1; RU7; Diele and Koch 2010). Fishers distinguish male and female crabs by differences in body shape, reproductive organs, hairiness, and distinct tracks in the burrow (RU6). There is a positive feedback loop between mangrove production, beneficial soil bacteria and crab foraging, during which increases in one create direct or indirect increases in the other two (RU3; RS6; Koch and Nordhaus 2010). Crab density in Northern Brazil is high, estimated at 1,650,000 individual crabs per square kilometer in a healthy forest (RU5; RS5; Diele and Koch 2010). The number of crabs caught per 
fisher per day may be up to 300, with average catch per person per day (CPUE) around 150 crabs (RU5; Nascimento et al. 2015). Mangrove crabs are sold live or as cooked and processed meat. Live crabs are sold to patrons (middlemen) for 0.35-0.85 Reais per crab ( US\$0.1-0.25); processed meat is sold for 8-17.00 Reais ( $\sim$ US\$2.25-5.50) per kilo locally depending on the season and quality (RU4), and 60-80 Reais in the state capital Belém.

\section{$\operatorname{Actors}(A)$}

Multiple actor groups exist in the CT RESEX (Glaser and da Silva Oliveira 2004) and the second-tier variables of the SESF could be applied to each separately (McGinnis and Ostrom 2014). We focus on fishers and RESEX residents as a combined actor group whose livelihoods are directly affected by the RESEX program.

There are $\sim 4200$ families distributed across 50 communities (A1) who are considered residents with the rights to use the CT RESEX. Communities are connected to each other and Bragança town by a main asphalt road and secondary dirt roads; the latter are difficult to access during the rainy season (A4). A majority of fishers and residents, highly livelihood dependent on extracting local natural resources, are either self-employed or contracted to extract crabs or wood for processing companies. Financial hardships can be directly related to seasonal and other changes in the local availability of crabs and seasonal fishing closures during crab reproduction periods (A8). The socioeconomic conditions of rural dwellers in the CT RESEX are low income and subsistence based, with little access to many public services and infrastructure for many, but not all communities (A2).

Because of the scattered nature of village locations and difficulties in accessing the mangrove, many fishers harvest in the areas surrounding their places of residence or close to the coastline with boat access (A3: Thies-Albrecht 2016). Accessing mangrove crab resources requires local knowledge on tidal flows, estuary navigation, and the ability to identify crab burrows, size, and the sex of the animals (A7). Fishers with boats have greater access to distant mangrove areas, but also incur higher time and monetary costs. Collecting crabs is only legal by hand, and some permits for small net traps are given (gancho; http://siscom.ibama.gov. $\underline{\mathrm{br} /})$, but poles with large fixed hooks are increasingly used to get crabs out of burrows deeper than an arm's length (A9). Hooks can injure undersized or female crabs, which should not be harvested. After about 2005, some fishers in the region started to use plastic snare-like traps (redinhas) positioned at the top of a crab burrow. Snares are picked up on return trips, but some are forgotten, leaving plastic and dead crabs behind. Crabs are sold live to patrons (middlemen) or cooked and processed by women in the household for sale, or most recently processed by employees in a nascent artisanal processing industry. There are currently three processing businesses, but overall entrepreneurship and leadership in the CT RESEX are weak (A5). In a few villages, private businesses for crab collection and processing are being established, but this is being initiated by outsiders (nonresidents of RESEX). Most fishers are beholden to patron-client systems, which are often exploitative, but their only market access option (A4; A6; I4). In great contrast to the period between 1996-2005 (Glaser and da Silva Oliveira 2004, Glaser et al. 2010a), today there is a general lack of capable individuals willing to invest the time and effort to participate in RESEX politics or to take community leadership roles, for example in the Deliberative Council (DC). This could be related to the fact that no compensation for lost income is paid to small-scale producers who engage with the RESEX, disagreements between leaders due to disputes over institutional power in management, a lack of leadership continuity, along with the minimal participation of young people. Many community leaders are older and no longer fish; many of our interviewees reported initial participation but dropped out over time because of a lack of financial incentives or perceived benefits. Fishing is perceived as a better use of time, resulting in direct income (A6). Recent programs to build leadership capacity organized by UNESCO and Rare (NGO) have attempted to address this challenge.

\section{Governance systems ( $G S$ )}

The Caeté-Taperaçú RESEX was created in 2005 as a comanaged marine extractive reserve in which the rights to extract resources are given to an association of users to collectively develop rules (GS1; GS4). A timeline of key political events from 1990 to 2017 are shown in Appendix 2. The comanagement rights apply exclusively within the RESEX boundaries (GS2; Fig. 1). To address identified user conflicts relating to the local mangroves, local village residents were offered comanagement rights to address conflicts under the RESEX legal framework, then administered by the Conselho Nacional de Populacoes Tradicionais (National Council of Traditional Populations, CNPT), the predecessor of ICMBio. Since 1998, extensive diagnostic assessments have been conducted in the area by the local university, the rural farmers union, and CNPT/IBAMA. These contributed to the initiation of the RESEX in 2005. Despite these earlier efforts, the initial diagnostic phase to assess the status of the area or the current management plan is stated in the official document as not having begun until 2009 (GS10). The final management plan was only published in 2012, stating the goal of "...conservation, preservation and sustainable use of natural resources...to improve the living conditions and enhancement of traditional culture for people...residing in and/or around [the RESEX]" (ICMBio 2012:9).

The core comanagement board of the CT RESEX is the Deliberative Council (DC). The DC is facilitated by ICMBio and comprises local, regional, and national actors. The DC contributes to "actions aimed at the implementation of the Management Plan," (ICMBio 2012:13), deciding on rules or changes to rules (GS6). DC member organizations are considered to be the rule makers of the RESEX (GS5). The 50 communities are divided into 8 representative groups (polos). Table 2 shows member organizations of the DC. The management plan was generated and approved by ICMBio and the DC. Appendix 3 shows its current rules-in-use (GS6). The operational rules for crab fishing focus on user rights, similar to those in other benthic and crustacean fisheries (Basurto et al. 2013, Partelow and Boda 2015). A monitoring program (Program of Voluntary Environmental Agents) was created by IBAMA in which some residents received training in environmental education, protection, preservation, and conservation of natural resources in the RESEX area (IBAMA 2005). However, the program was largely unsuccessful because of conflicts with monitoring and rule compliance involving relatives and friends of volunteer agents (Amaral et al. 2008) and was thus discontinued in 2013 (IBAMA 2013). Therefore, although graduated sanctions exist, they are no 
Table 2. Stakeholder groups, each with one seat on the RESEX Deliberative Council (RESEX = marine extractive reserve).

\begin{tabular}{|c|c|c|c|}
\hline $\begin{array}{l}\text { Organization type } \\
\text { (GS5) }\end{array}$ & Stakeholder group & Role/mission & $\begin{array}{l}\text { Level of } \\
\text { jurisdiction }\end{array}$ \\
\hline \multirow{11}{*}{$\begin{array}{l}\text { Public sector } \\
\text { GS5.1 }\end{array}$} & Chico Mendes Institute for Biodiversity & Direct management, implementation, and oversight of & Local \\
\hline & Conservation (ICMBio) & RESEX areas. & $\begin{array}{l}\text { Regional } \\
\text { National }\end{array}$ \\
\hline & Camara Municipal of Vereadores & $\begin{array}{l}\text { Legislative body of the municipal administration } \\
\text { promulgates organic law and legislative inspection. }\end{array}$ & Local \\
\hline & City Council of Bragança & Seat of executive power, enforces laws. & Local \\
\hline & $\begin{array}{l}\text { National Institute of Colonization and } \\
\text { Agrarian Reform (INCRA) }\end{array}$ & $\begin{array}{l}\text { Advanced agrarian reform through formalizing land tenure } \\
\text { for economic development. }\end{array}$ & National \\
\hline & $\begin{array}{l}\text { Secretary of State for the Environment of Pará } \\
\text { (SEMA) }\end{array}$ & Regional office of national environment secretary. & Regional \\
\hline & $\begin{array}{l}\text { Institute of the Environment and Renewable } \\
\text { Natural Resources (IBAMA) }\end{array}$ & $\begin{array}{l}\text { Oversees ICMBio, provides social and environmental } \\
\text { research, permits for resource management, and manages } \\
\text { constitutional framework for the RESEX (e.g., licensing, } \\
\text { user registration, law). }\end{array}$ & National \\
\hline & $\begin{array}{l}\text { Brazilian Institute for Geography and statistics } \\
\text { (IBGE) }\end{array}$ & Collect and analyze geographic information at national level. & National \\
\hline & Federal University of Pará (UFPA) & University that provides scientific support and consultation. & $\begin{array}{l}\text { Local } \\
\text { Regional }\end{array}$ \\
\hline & $\begin{array}{l}\text { Instituto Federal de Educação, Ciência e } \\
\text { Tecnologia do Pará (IFPA) }\end{array}$ & $\begin{array}{l}\text { Provides scientific and technological support and } \\
\text { consultation. }\end{array}$ & $\begin{array}{l}\text { Local } \\
\text { Regional }\end{array}$ \\
\hline & $\begin{array}{l}\text { Pará's Federal Institute for Education, Science } \\
\text { and Technology }\end{array}$ & & \\
\hline \multirow{15}{*}{$\begin{array}{l}\text { Community-based } \\
\text { GS5.4 }\end{array}$} & Polo Tamatateua & Represent communities (in separate groups) in the $\mathrm{CT}$ & Local \\
\hline & Polo Center & RESEX. & \\
\hline & Polo Caratateua & & \\
\hline & Polo Acarajó & & \\
\hline & Polo Treme & & \\
\hline & Polo Bacuriteua & & \\
\hline & Polo Ajuruteua & & \\
\hline & Polo Campos & & \\
\hline & $\begin{array}{l}\text { Association of users CT RESEX } \\
\text { (ASSUREMACATA) }\end{array}$ & $\begin{array}{l}\text { Represents registered users of the CT RESEX as a whole. } \\
\text { Holds land title to CT RESEX. Responsible for } \\
\text { implementing rules of the management plan. }\end{array}$ & Local \\
\hline & Women Movement Paraense Northeast & $\begin{array}{l}\text { Social feminist movement that has been implementing a } \\
\text { network to avoid violations of women's human rights. }\end{array}$ & Regional \\
\hline & Union of Artisanal Fishers of Bragança PA & Represents the rights of artisanal fishers in a local context. & Local \\
\hline & Breeders and Bragança Beekeepers Association & Local NGO. & Local \\
\hline & $\begin{array}{l}\text { National Commission for strengthening of } \\
\text { extractivist reserves and coastal extractivist } \\
\text { towns (CONFREM) }\end{array}$ & Represent the rights of extrativists in a national context. & National \\
\hline & Fishermen cooperative (COOPA) & Fisher organization. & Local \\
\hline & $\begin{array}{l}\text { Fishing and aquaculture cooperative of the } \\
\text { Salgado region (COPESCAR) }\end{array}$ & Organize the production and commercialization of fishers. & Local \\
\hline \multirow{4}{*}{$\begin{array}{l}\text { Hybrid } \\
\text { GS5.5 }\end{array}$} & Enterprise Technical Assistance and Rural & Official organization that promotes Technical Assistance & Local \\
\hline & Extension Pará (EMATER) & and Rural Extension & Regional \\
\hline & Pastoral fishermen commission (CPP; Catholic & Promote services for fishers as support for social & Local \\
\hline & Church) & organization. & $\begin{array}{l}\text { Regional } \\
\text { National }\end{array}$ \\
\hline
\end{tabular}

longer enforced by registered users themselves or by external authorities (Ostrom 1990). However, registered users are obliged to pay a tax to the DC for monitoring and enforcement. A 50year concession is given to the association of users (ASSUREMACATA) with rights to grant access, resource extraction, management, and exclude others, but the alienation rights and the actual land title are held by the Brazilian state (GS7; Schlager and Ostrom 1992). Table 2 shows the multilevel network structure for comanagement (GS9).
The RESEX program was subsidized with development aid through the Bolsa Verde program, targeting households directly dependent on resource harvesting. To qualify for Bolsa Verde, families must be registered residents of the RESEX with the ICMBio office and earn less than 70 Brazilian Reais ( US\$22) per family member per month. The program provides 300 Brazilian Reais ( US\$95) every two months with the aim to reduce overharvesting due to financial needs. Approximately 3700 families are part of the program, increasing their income 
significantly. However, criticism for the Bolsa Verde program is that it only focuses on terrestrial resources, which may result in greater pressure on marine resources because of the displacement of terrestrial harvesting (Kasanoski 2016).

\section{Related ecosystems ( $E C O$ )}

Low-lying mangrove estuaries are vulnerable to sea-level rise (ECO1). Landward shifts of the mangrove/marsh in the Bragança region to higher ground have been observed since 1972 and have been linked to increases in mean sea level (Lara et al. 2010). Mangroves are moderately resilient to sea-level rise, but this can be compromised by human activities that disturb sedimentation processes (Krauss et al. 2014, Woodroffe et al. 2016). In Bragança, disturbances include the removal of crabs, altering river flows around settlements, forest degradation due to wood harvesting (Glaser et al. 2003), and infrastructure development such as the road construction through the middle of the Caeté peninsula causing considerable erosion.

\section{Interactions (I)}

Key interactions 1: altered social and political momentum In 2005, comanagement was new for coastal populations that were keen to assume some control over decision making on the natural environment their livelihoods depended on (Glaser and da Silva Oliveira 2004, Diele et al. 2010). The CT RESEX was officially declared in 2005 (A3) after four years of preparatory meetings, networking, collaborative analyses, and capacitation work with local residents, NGOs, and unions and a further two years of legislative processing by the responsible agencies at the national level such as IBAMA/CNPT. In the first decade, the incentive to influence and implement the rules most central to local livelihoods was a key driver for local participation to support the RESEX (GS10; Glaser and da Silva Oliveira 2004). However, this momentum changed. Administrative delays, altered livelihood options, and political favoritism all played a role. Previous leadership and momentum dissipated as numerous key individuals from the earlier period were no longer involved, and leadership of political movements without much local knowledge took over. This hindered local participation and representation for continued action. When the RESEX was finally created with a formal management plan, nearly 10 years after its inception, changing leadership and shifting perceptions of its purpose had reduced local motivation for continued effort and involvement.

\section{Key interactions 2: Shifting perceptions, communication, and} location

In the late 1990s and early 2000 s, there was a high level of social energy that initiated and sustained collective efforts to establish comanagement. However, local perceptions of the purpose and benefits RESEX comanagement would bring began to change. In its initial period, the RESEX rationale focused on empowering local communities to be semiautonomous in how they regulate the use, management, and conservation of local natural resources. As the program took shape however, the significant social benefits such as free houses, green scholarships, and a range of durable consumer goods (e.g., fridges and stoves) led the local residents to start perceiving the RESEX as a government social aid program. This was in full accord with the RESEX objective to include traditional populations into the national development process (Allegretti 1987, 1994). During this social development process, achieved in a period of socialist government, RESEX was associated with multiple social development forces (Movimento sem Terra, Bolsa Verde). The impressive range of associated material benefits shifted local perceptions and expectations away from the collective efforts for natural resource comanagement. With material gains, livelihoods depended less on the mangroves. Outside families were also motivated to move into the RESEX area in which help with their substantial development needs such as housing, education, and consumer goods, was available. Fishers also migrated to the region as it became a commercial hub. As a result, the number of registered RESEX users increased substantially and before long subsidized housing was no longer available for everyone who needed it.

Skepticism of the social development programs was related to the whole RESEX program, grounded on the newly emerged idea that the purpose of the RESEX was to distribute subsidized social development aid. These developments undermined the local incentives to work together through comanagement, and thus to take and implement collective decisions for the area and its future. Success in establishing sustainable human-nature relations through collective action was thus displaced by falling dependence on local mangrove resources, by dysfunctional leadership, and by multiple social subsidies, which were perceived as failing to deliver evenly distributed benefits. The social and political momentum for RESEX thus stagnated along with the trust and confidence of those working to achieve its original goals.

Unclear communication about the purpose of RESEX and other development programs contributed substantially to why perceptions shifted. Information flow between all actors was minimal and influenced by competitions for political influence. Many residents tried to capitalize on development programs for short-term gains. For the average mangrove user, it became easier to improve their socioeconomic situation through development aid than by investing in the comanagement of resource harvesting. Those in leadership positions are reported to have competed for power and influence rather than investing in long-term efforts to establish collective governance through comanagement.

Three information flow bottlenecks can be identified as influential. First, only a few key individuals were well informed about the purpose and motivations for the RESEX, and the number of actively engaged individuals has decreased over time. Second, ICMBio lacked the monetary and human resources to develop communication channels, disseminate official information, and train community leaders, thus distorting real information about the purpose of the RESEX with rumors, discontent, and politically motivated misinformation. Third, with 50 geographically isolated communities, official information did not reach many actual mangrove resource users. Communities have been historically separated, in part because of the characteristics (RS9) of the resource system (mangrove) and resource units (mangrove crabs). Mangrove crabs live rather stationary and nonmigratory adult lives, and fishing areas seem to have emerged according to the local ecological knowledge about crab distributions, with certain productive fishing areas being more easily accessible than others. Communities have likely been established around these areas because of patterns in resource harvesting, benefiting from known routes through the difficult- 
to-navigate mangroves (Thies-Albrecht 2016). Although there is no formal property rights system for fishing, informal fishing areas are recognized and implemented by local fishers. Rights to access fishing areas are often temporally delimited, relating more to when you fish than where (Oliveira and Maneschy 2014). Difficulties in communication and market access can be seen as a geographical consequence of how local communities have codeveloped informal fishing areas with local ecological knowledge of the mangrove and crab populations. The very close link between mangrove-adjacent villages and their surrounding resources still suggests a great need for a sustainable local extractivism that resolves difficult and spatially reinforced socialecological linkages.

Key interactions 3: Patron-client relationships and socialecological traps

The price of mangrove crabs has increased over time, driven by increasing demand from markets for seafood throughout Brazil. The State of Pará is a top provider of seafood nationally. However, prices received by local fishers remain low because of exploitative patron-client relationships. Patrons control market access for most fishers who reside remotely and cannot transport crabs to market independently. Profits do not trickle down to local fishers beholden to patrons who offer low prices, increasing their own gains. Fishers often cannot select alternative patrons because there are few to choose from.

Exploitative patron-client systems can lead to overharvesting because increased extraction is the only way to make a better living when receiving low prices. Overharvesting is also motivated by high crab mortality during transportation (25-55\%; Legat et al. 2006). A ventilated plastic box with a water-soaked lining is mandated but unlikely to be used by many or enforced (MPA 2013). Similar situations have been described in the literature as social-ecological traps (Boonstra et al. 2016). Overharvesting pressures in combination with difficulties in accessing new mangrove areas because of informal fishing areas, have forced fishers to begin harvesting smaller (illegal) crabs locally, which have lower market value. Harvesting greater quantities of smaller crabs is necessary to earn a stable income. Fishers often become indebted to patrons, and loans are difficult to pay back because of limited crab availability and tidally limited fishing time, and by the lack of alternative livelihood opportunities. This is a selfreinforcing negative feedback loop. Low prices lead to overharvesting to maintain a stable income, slowly degrading ecological productivity and economic value of the resource over time. This is termed "a vicious circle" (Glaser et al. 2010b). This undermines the integrity of the mangrove forests as a mechanism of social insurance for the poor who rely on local natural resources when other economic and food options are not available.

\section{Key interactions 4: Institutional fit and equitable participation in} comanagement

Transitioning from no formal governance (e.g., no written rules for resource use or for participation in decision making) to comanagement is an institutional novelty for most residents. Traditional populations are being challenged to reconfigure their institutional space, the social structures within which they interact, engage with the concept of governance, and use local knowledge to make beneficial changes to their own resource use behavior (Esterci 2002, Teisserenc 2014, DiPaolo 2017). Although the informal institutions of the early 1990s are now formalized in the RESEX rules, informal institutions have continued to change. Formal RESEX rules do not intend to incorporate existing informal institutions, but such adaptiveness is needed to make the RESEX work. Many fishers find participation in RESEX-related meetings confusing and ineffective, despite the goal of creating a more equitable deliberative environment. Equitable participation is a practical challenge because some actors have more knowledge about the RESEX and are more familiar with participating in formal political meetings, such as members from local universities, ICMBio, and the municipality. This can reinforce existing narratives of disempowerment and mistrust through formalizing governance and procedural approaches that favor the participation of the actor groups who designed them. Although residents have the largest number of seats on the Deliberative Council, their influence is disproportionately small (Silva-Junior 2013, Narahara 2014).

Key interactions 5: Harvesting closures and compensation A temporary ban on crab harvesting (I1) occurs during key reproductive periods called andadas (Diele and Koch 2010, MAPA 2017; GS6). During reproduction, crabs spend longer periods outside their burrows, leaving them exposed to harvesting (RU2). Fishers are not compensated for lost income during seasonal closures, and there is little rule enforcement relating to the collection of crabs by hobby and leisure collectors during the andadas. Fishers requested closures themselves, with the condition that they can receive compensation (seguro defeso) for not fishing from January to April during crab reproduction and from June to September when crabs change their carapace (Nascimento et al. 2015). However, communication about official rules and seasonal closures is minimal in some areas, many fishers simply do not know about them. Santos and Schiavetti (2017) alert that there is a lack of clarity in Brazilian environmental legislation regarding the concept of the right to use the coastal environment and contradictions between Brazilian environmental legislation and some rules in marine RESEX areas. The lack of compensation for lost income during closed periods with few alternative income sources and low knowledge of rules means that fishing during seasonal closures largely continues even when it is well known as bad practice. When income is low, the mangrove acts as a form of insurance for many families who harvest local resources for subsistence (such as crabs and wood) when they cannot purchase additional food or supplies (A2). Overharvesting driven by commercial markets undermines the resilience of the ecosystem and crab populations, which in turn undermines the ability of ecosystems to act as a reliable source of food security and insurance that can support social welfare.

\section{Outcomes (O)}

Our results recognize complexity in an attempt to avoid overly simplified models of SES outcomes and their drivers. Trends in recent progress toward CT RESEX goals can be briefly synthesized from our analysis. Resource dependent livelihoods remain vulnerable to ecological and social changes. Comanagement has not motivated sufficient collective action to continue the momentum for the substantial changes needed to pull fishers out of social-ecological traps or to bring diversified economic opportunities and decrease the fragile dependence on local natural resources. Social development programs attached to RESEX have made progress on reducing local resource 
dependence, but this is not because of successful comanagement. Collective action is a foundation for comanagement success but collective efforts have not occurred to a sufficient degree to suggest comanagement has been successful in achieving RESEX goals (O1). Significant barriers are apparent. There are many different social and ecological reasons why collective action and comanagement have stagnated. The SES conditions influencing collective action from the SESF are shown in Table 3. Viewed in combination, we can see how current theories help explain hindered progress. Beyond needed collective action on the Deliberative Council and among residents to motivate political will, there remains a need to improve livelihoods and social outcomes through creating better opportunities for livelihood diversification, education, and empowerment. Many social performance measures have remained the same since pre-RESEX. Ecologically, crab population data and harvesting rates suggests stability, although evidence for increased mangrove degradation, gradual increases in catch-per-unit effort, and the number of fishers suggests that this will likely degrade ecological health if continued at current rates (O2). Any substantial ecological degradation or changes to resource abundance and distribution would certainly bring reciprocal social impacts. Sea level rise, human migration into the area, the development of industry, and political instability are likely to bring increasing pressures and challenges for effective governance, but their precise impacts are difficult to assess $(\mathrm{O} 3)$.

\section{DISCUSSION AND CONCLUSIONS}

Marine RESEX programs exist throughout Brazil and their unique institutional arrangements have motivated numerous studies (da Silva 2004, Diegues 2008, Santos and Schiavetti 2014, Nobre et al. 2017) examining the inclusive approach to MPA governance, which combines human well-being objectives and conservation goals (Bennett et al. 2017). However, marine RESEX have struggled to achieve success in mangrove conservation (Santos and Schiavetti 2014, Borges et al. 2017) in line with MPAs globally (Halpern 2014, Bennett and Dearden 2014). The institutional complexity of MPA governance continues to challenge scholars and practitioners (Jones et al. 2013, Alexander et al. 2016).

Lessons can be drawn from this analysis allowing for general conclusions about the wider Brazilian and MPA context. Regional and local ICMBio offices have few resources for implementation and outreach, mirroring findings showing that a lack og human and financial resources are a considerable barrier for MPA success worldwide (Pomeroy et al. 2005). The benefits of RESEX comanagement have not always been clear to remote resource users who would benefit most from its implementation; and decision making has not always represented the diversity of actors' socioeconomic conditions and livelihoods (Santos and Brannstrom 2015). This supports the shift toward making MPA governance more inclusive and participatory with local people to enhance success (Glaser et al. 2010b, Tam 2015). Social and institutional differences as well as the historical marginalization of rural fishing communities in national policy have created challenges with communication about the purpose of RESEX and power imbalances between actors involved in governance from the local to national levels. The perceived legitimacy of and trust in the RESEX as an institution, to collectively invest in, was therefore never fully established. Local and regional politicians have used the RESEX and associated social development programs to leverage their own political agendas, often misaligned with the original comanagement goals.

Although collective action of resource users is a necessary pillar of comanagement success, so is strong and continued state commitment. Resilience to shifting social and political momentum requires mechanisms and platforms in which deliberation, knowledge exchange, and social learning among actors can inform decision making (Armitage et al. 2008, Reed et al. 2010, Plummer and Hashimoto 2011, Tengö et al. 2014). Facilitating iterative deliberation and capacity building were initially recognized as necessary, but implementation is difficult without well-supported and well-intentioned leadership, and without substantial institutional transformation to render the deliberation process itself more inclusive. Continued investments to maintain communication and capacity building efforts would certainly be beneficial to address shifting perceptions and political discontent among local actors. For example, continued funding for local ICMBio offices to conduct outreach programs and the dissemination of materials on the RESEX program through news, radio, or at specific community events. Also, training programs for local leadership and community members to build more capacity for self-organization and political involvement would be beneficial.

Ostrom's design principles provide a theoretical framework for evaluating enabling conditions for community-based governance, and studies of other marine RESEX show that comanagement has provided these conditions in concept, but that they have been difficult to establish in practice (da Silva 2004, Nobre et al. 2017). This study draws similar conclusions, expanding on the design principles by applying broader theories of collective action. Finding effective conflict resolution mechanisms through the Deliberative Council, although envisioned, has been difficult because the active and regular participation of local actors was not successfully facilitated. Leadership accountability and consensus building among fishers and RESEX members have suffered in the context of other social development programs, not least because of a lack of communication and well-established collective-choice rules for regular meetings and decision making. As of 2016, we observed a misfit between formal comanagement rules and local informal institutions; many residents are not familiar with self-organizing activities or regular participation in local governance. This study aligns with similar reflections and concerns in other RESEX areas (da Silva 2004, Di Ciommo 2007, Vadjunec and Rocheleau 2009, Santos and Schiavetti 2014, Erler et al. 2015, Santos and Brannstrom 2015, Le Tourneau and Beaufort 2017, Nobre et al. 2017). Setting up comanagement is not enough; continued efforts to create more user engagement and stronger institutions that can establish harvesting rules congruent with local livelihood sufficiency and ways to control adherence to them are needed. Despite these challenges, there remains political momentum to establish new reserves in other areas; coastal governance in the RESEX format still symbolizes empowerment and the inclusion of marginalized rural populations into national governance (Santos and Schiavetti 2014, Santos et al. 2017).

From the perspective of resource users, high dependence on local natural resources with low market values due to suboptimal 
Table 3. Social-ecological systems framework (SESF) second-tier variables and their case value in the Caeté-Taperaçu (CT) RESEX associated with hypotheses of collective action theory (Ostrom 1990, Poteete et al. 2010, Cox 2014). A general trend is shown for current case values, and a brief contextual explanation. RESEX = marine extractive reserves.

\begin{tabular}{|c|c|c|c|c|}
\hline SESF & $\begin{array}{l}\text { Theoretical claim/hypothesis for } \\
\text { collective action (CA) }\end{array}$ & Case value & Case trend & Case explanation \\
\hline A5 & $\begin{array}{l}\text { Accountable leadership } \\
\text { increases likelihood of CA. }\end{array}$ & Low & Unclear & $\begin{array}{l}\text { Shifting social momentum and lack of capacity minimizes } \\
\text { motivation to participate. }\end{array}$ \\
\hline $\begin{array}{l}\text { A6; I2; } \\
\text { GS3 }\end{array}$ & $\begin{array}{l}\text { Communication increases likelihood of } \\
\text { CA. }\end{array}$ & Low & Unclear & $\begin{array}{l}\text { Geographical isolation and lack of effective mechanisms for } \\
\text { communication. }\end{array}$ \\
\hline GS6; I4 & $\begin{array}{l}\text { Conflict resolution mechanisms increase } \\
\text { likelihood of CA. }\end{array}$ & Low & Unclear & $\begin{array}{l}\text { Lack of regular Deliberative Council meetings. Lack of } \\
\text { monitoring and rule enforcement. }\end{array}$ \\
\hline GS6 & $\begin{array}{l}\text { External sanctions can override } \\
\text { prosocial motivations, decreasing } \\
\text { likelihood of CA. }\end{array}$ & Low & Unclear & Minimal self-monitoring or external sanctioning occurs. \\
\hline A2 & $\begin{array}{l}\text { Cultural heterogeneity decreases } \\
\text { likelihood of CA. }\end{array}$ & Medium & Stable & $\begin{array}{l}\text { Informal social and cultural institutions differ between actor } \\
\text { groups on Deliberative Council. }\end{array}$ \\
\hline $\mathrm{A} 2$ & $\begin{array}{l}\text { Economic heterogeneity of actors } \\
\text { increases likelihood of CA. }\end{array}$ & High & Stable & $\begin{array}{l}\text { Most residents have very low income, external actors are } \\
\text { wealthier and can invest more. }\end{array}$ \\
\hline A1 & $\begin{array}{l}\text { Smaller groups increase likelihood of } \\
\text { CA, reducing transaction costs. }\end{array}$ & High & Increasing & $\begin{array}{l}4200 \text { registered families. Many other actors are involved (e.g., } \\
\text { NGOs, political, academics, state). }\end{array}$ \\
\hline A2; A 8 & $\begin{array}{l}\text { If actors have a common interest, } \mathrm{CA} \text { is } \\
\text { more likely. }\end{array}$ & Medium & Unclear & $\begin{array}{l}\text { Undermined by shifting perceptions and motivations to } \\
\text { participate in RESEX. }\end{array}$ \\
\hline A8 & $\begin{array}{l}\text { High dependence on local natural } \\
\text { resources can motivate CA. }\end{array}$ & High & Stable & $\begin{array}{l}\text { Residents are highly and directly dependent on local resources, } \\
\text { but other RESEX actors less so. }\end{array}$ \\
\hline A6 & $\begin{array}{l}\text { Past collaborations increase likelihood of } \\
\text { social capital and therefore CA. }\end{array}$ & Medium & Decreasing & $\begin{array}{l}\text { Early social-political momentum initiated collective efforts, but } \\
\text { this diminished, past leaders are no longer involved. }\end{array}$ \\
\hline A2; A6 & $\begin{array}{l}\text { If costs bring proportional distribution } \\
\text { of benefit, CA is more likely. }\end{array}$ & Medium & Unclear & $\begin{array}{l}\text { Short-term benefits are few; long-term benefits are difficult to } \\
\text { prioritize and incentivize. }\end{array}$ \\
\hline I2; I7, I8 & $\begin{array}{l}\text { If transaction costs of } \mathrm{CA} \text { are high, it is } \\
\text { more difficult. }\end{array}$ & High & Unclear & $\begin{array}{l}\text { Participation difficult with institutional differences. Long-term } \\
\text { character of benefits reduces short-term incentives. }\end{array}$ \\
\hline A1 & $\begin{array}{l}\text { If user group boundaries are clear, } \mathrm{CA} \text { is } \\
\text { more likely. }\end{array}$ & High & Stable & $\begin{array}{l}\text { RESEX has clear user group boundaries. Users need to } \\
\text { register to receive benefits. }\end{array}$ \\
\hline GS6; GS8 & $\begin{array}{l}\text { Graduated sanctions increase } \\
\text { compliance and trust in institutions for } \\
\text { CA. }\end{array}$ & Medium & Unclear & $\begin{array}{l}\text { First verbal or written warning, then } 30-90 \text { day suspension of } \\
\text { extraction rights, then permanent exclusion. However, no cases } \\
\text { of enforcement. }\end{array}$ \\
\hline GS6.2 & $\begin{array}{l}\text { Collective choice rules for decision } \\
\text { making increases likelihood of CA. }\end{array}$ & Medium & Unclear & $\begin{array}{l}\text { RESEX ensures collective choice arrangements through the } \\
\text { DC. A legal framework exists, but this does not work well in } \\
\text { practice. }\end{array}$ \\
\hline GS6.3 & $\begin{array}{l}\text { Rules fit (e.g., accepted by) outside } \\
\text { authorities increases likelihood of CA. }\end{array}$ & High & Stable & Constitutionally mandated. \\
\hline GS4; GS8 & $\begin{array}{l}\text { Governance fit to local needs and } \\
\text { institutions increases likelihood of } \\
\text { continued CA. }\end{array}$ & Medium & Unclear & $\begin{array}{l}\text { RESEX is a step in the right direction. Comanagement aims to } \\
\text { fit and evolve from local informal institutions. Initial social } \\
\text { energy has declined, leaving an unclear path forward. }\end{array}$ \\
\hline GS9 & $\begin{array}{l}\text { Nested levels of governance increases } \\
\text { likelihood of continued CA. }\end{array}$ & High & Stable & See Table 2. \\
\hline RS2 & $\begin{array}{l}\text { Clear biophysical boundaries increase } \\
\text { likelihood of CA. }\end{array}$ & Low & Stable & $\begin{array}{l}\text { Boundaries are difficult in practice, and the mangrove } \\
\text { ecosystem is continuous. }\end{array}$ \\
\hline RS3 & $\begin{array}{l}\text { Moderate biophysical size is more } \\
\text { conducive to CA. }\end{array}$ & Medium & Stable & $\begin{array}{l}\text { Communities are scattered with isolated fishing areas, but } \\
\text { social interactions are possible. }\end{array}$ \\
\hline RS5; RU2 & $\begin{array}{l}\text { Productivity is curvilinear for CA, too } \\
\text { high or low decreases likelihood. }\end{array}$ & High & Decreasing & $\begin{array}{l}\text { Crab production is very high, which may be giving a false } \\
\text { impression of stability and need for CA among fishers. }\end{array}$ \\
\hline RS7; RU7 & $\begin{array}{l}\text { System predictability increases likelihood } \\
\text { of CA. }\end{array}$ & Medium & Unclear & $\begin{array}{l}\text { Crab reproduction is highly predictable, closure rules } \\
\text { potentially effective if followed. Other factors like sea-level rise } \\
\text { decrease predictability. }\end{array}$ \\
\hline RU6; I1 & $\begin{array}{l}\text { Resources with distinctive markings can } \\
\text { be harvested or managed more } \\
\text { selectively, increasing likelihood of CA. }\end{array}$ & High & Stable & $\begin{array}{l}\text { Easy distinction of crab gender increases ability to harvest } \\
\text { selectively, reducing the extraction of reproductive females. }\end{array}$ \\
\hline RU4 & $\begin{array}{l}\text { Low value produce may not incentivize } \\
\text { CA, but high value produce can lead to } \\
\text { overexploitation that is too fast for } \\
\text { institutions to respond. }\end{array}$ & Medium & Increasing & $\begin{array}{l}\text { Fishers receive low value from patrons, which does motivate } \\
\text { CA as they need to spend more time fishing. Overall crab } \\
\text { prices are going up. However, institutional responses are slow, } \\
\text { taking decades to establish RESEX in practice. }\end{array}$ \\
\hline
\end{tabular}


patron-client relations makes developing incentive structures for participation in comanagement difficult when time, money, and motivations are scarce and volatile. Patron-client systems in smallscale fisheries might evolve to provide mutual benefits (FerrolSchulte et al. 2014), but the remote locations, high dependence on few patrons, and increasing external market prices in the CT RESEX make this, as many other patron-client relations (Glaser et al. 2015) strongly asymmetric. Small-scale fisheries have been facing these challenges for decades, often driven by the integration of fish products into global markets with complex supply chains that do not bring proportional economic gains back to rural fishers (Berkes et al. 2006, Eriksson et al. 2015, Bennett and Basurto 2018). Long-term sustainable exploitation is difficult to adhere to when short-term gains are needed, often driving overexploitation to meet basic needs or pay back debts (Glaser et al. 2010a). Incentives to change harvesting behavior and support governance reform are low when promised reform to establish the RESEX has taken more than a decade.

Comanagement may only work when the intended beneficiaries are motivated to act collectively to support it. Motivations for self-organization among residents are affected by multiple factors, but this analysis has focused on how and why user perceptions form in relation to the legitimacy and usefulness of governance models. However, even if residents do view comanagement as beneficial, further consideration for how formal models of governance interact with existing local social and cultural institutions is necessary (Glaser et al. 2010b, Rahman et al. 2017) to achieve an adequate level of institutional fit to the socialecological context (Olsson et al. 2007, Epstein et al. 2015).

A growing body of literature, including this study, suggests the need to consider social-ecological complexity in the design and successful long-term implementation of comanagement (Armitage et al. 2009, Bodin 2017). Outcomes that are collectively accepted as beneficial are more likely to be achieved when governance institutions are adaptable, i.e., can evolve to a changing social-ecological context (Plummer and Hashimoto 2011, DeCaro et al. 2017, Whitney et al. 2017). Limited knowledge on SES complexity and the integration of such knowledge into policy practice obstruct the CT RESEX and other MPAs (Pollnac et al. 2010, López-Angarita et al. 2014). This relates to recognizing local traditional (Tengö et al. 2014), system, target, and transformative knowledge (Partelow and Winkler 2016).

The SESF has proven to be a useful research tool for advancing this knowledge, helping to describe the complexity of variables and identifying knowledge gaps. The SESF is useful as an organizational and coding framework for analyzing large amounts of qualitative data. However, it is not obvious how the SESF can facilitate an analysis of the interactions between variables methodologically without better linking to theory. A theory such as collective action helps to unpack the potential explanations of why certain variables influence outcomes. However, understanding the interactive effects between variables, i.e., how clusters of independent variables interact to shape outcomes, is more difficult to measure empirically, hindering the development of theory to better understand complex SES. Further applications of the framework should focus on developing methods for analyzing the interactions between variables (Hinkel et al. 2015, Leslie et al. 2015, Partelow et al. 2018b). This study frames key interactions as the clusters of variables shaping important outcomes with thick qualitative descriptions. This is a different conceptualization of the interactions (I) variables as originally envisioned in the SESF because of the variables representing the spaces in which actors deliberate and make choices influencing the SES. Perhaps another way to view interactions between variables in the SESF, as done in this study, is to identify which variables interact to build on existing theories (e.g., social-ecological traps), or to generate new hypotheses of how variables interact in an SES.

Comanagement is as much about gaining the acceptance of local people through fostering an environment of social and political momentum as it is about establishing the appropriate formal governance arrangements (Bennett 2016, DeCaro et al. 2017). Further linking collective action and institutional change theories with MPA comanagement literature may provide a better understanding of these underlying social processes and how they can influence whether formal governance will work in practice (Schlüter et al. 2013, Weber de Morais et al. 2015). These processes are constantly fluctuating over time, thus comanagement requires persistent and regular efforts to maintain collective efforts. An understanding of how the CT RESEX evolved over time was useful to unravel the changing political narrative in the course of its establishment. Historical evidence and qualitative time-series data can provide useful insights, and further research can explore how the SESF can be applied to sort through the social-ecological complexity of changing political narratives and how this relates to collective action over different time periods (McGinnis and Ostrom 2014).

To conclude, we focus on specific aspects of our case study and policy reflections for marine RESEX throughout Brazil. The CT RESEX would benefit from numerous actions and policy changes that will move it more toward adaptive comanagement to better fit the context. Capacity building through increased communication and outreach to local residents seems necessary to regain trust and social energy to support RESEX by emphasizing the opportunities that can come from collective empowerment. Because there are many inherent system characteristics reducing the likelihood of collective action, developing the right incentives for all actors to participate needs to be acted on by addressing known barriers. If communities are isolated, disseminating information and communicating through local organizations, media publications, and radio may help to connect them. If local cultural institutions do not fit well with the formalities of governance, adapting meeting locations to community time preferences and locations may be useful. New formats for deliberation council meetings that can be adjusted to the social and economic constraints of fishers and RESEX community members (e.g., time, frequency, and locations of meetings) may create more space for equitable participation, building up social capital among actors, and creating knowledge exchange (Brewer 2012, Nenadovic and Epstein 2016). Programs supporting alternative livelihoods and recognizing the role of women in the emerging crab processing industry may help break the vicious circle of social-ecological traps and motivate renewed social energy for change among women who are typically not included (Santos 2015, Koralagama et al. 2017). Developing incentives to motivate young residents to step into leadership roles and into education opportunities outside the area could advance 
social development goals (Zurba and Trimble 2014). These changes are, of course, easier stated than done. It is also apparent that motivated individuals need to continue to invest time and effort into RESEX progress.

Overall, the CT RESEX in the context of Brazilian policy progress can be viewed as a positive development. However, broader critical reflection on the contemporary marine RESEX program is in order. Support communities with strong pre-existing selforganizational capacity was why RESEX was established; such was the case with the rubber harvesters in the era when Chico Mendes and other motivated groups struggled to make it happen. Formal comanagement was the last piece in their struggle for empowerment. In many RESEX areas now, formal comanagement is instead the starting point. Even if social and political momentum to establish a RESEX area was initially there, collective action must be continuously built up under conditions in which it might face considerable difficulties. This does not suggest that comanagement cannot work, but considerable adaptive capacity is needed for success.

Responses to this article can be read online at: http://www.ecologyandsociety.org/issues/responses. $\mathrm{php} / 10269$

\begin{abstract}
Acknowledgments:
We are thankful for all the interviewees and local residents in Bragança who have given their time and allowed us to explore their lives and challenges. We thank all of our colleagues who have pushed forward the MADAM collaboration and other related research over the last 20 years; our research would not have been possible without the work that came before us. Financial support from the Leibniz Centre for Tropical Marine Research (ZMT) is gratefully acknowledged. We very much appreciate the detailed and constructive comments from editors and reviewers that have helped shape the final versions of this manuscript. The publication of this article was funded by the Open Access Fund of the Leibniz Association.
\end{abstract}

\section{LITERATURE CITED}

Alexander, S. M., M. Andrachuk, and D. Armitage. 2016. Navigating governance networks for community-based conservation. Frontiers in Ecology and the Environment 14:155-164. http://dx.doi.org/10.1002/fee.1251

Allegretti, M. H. 1987. Reservas extrativistas: uma proposta de desenvolvimento da floresta Amazônica. Instituto de Estudos Amazônicos, Curitiba, Brazil.

Allegretti, M. 1994. Extrativistas: parâmetro para uma política de desenvolvimento sustentável na Amazônia. Pages 17-84 in A. Anderson and R. Arnt, editors. $O$ destino da floresta: reservas extrativistas e desenvolvimento sustentável na Amazônia. RelumeDumará, Rio de Janeiro, Brazil.

Álvarez-Romero, J. G., R. L. Pressey, N. C. Ban, K. VanceBorland, C. Willer, C. J. Klein, and S. D. Gaines. 2011. Integrated land-sea conservation planning: the missing links. Annual Review of Ecology, Evolution, and Systematics 42(1):381-409. http://dx. doi.org/10.1146/annurev-ecolsys-102209-144702

Amaral, L., O. Almeida, and D. G. McGrath. 2008. Co-gestão e o sistema de monitoramento voluntário: a desistência dos agentes mmbientais voluntários no Baixo Amazonas. Pages 1-13 in IV Encontro Nacional da Anppas. Brasilia, Brazil.

Armitage, D., M. Marschke, and R. Plummer. 2008. Adaptive comanagement and the paradox of learning. Global Environmental Change 18(1):86-98. http://dx.doi.org/10.1016/j.gloenvcha.2007.07.002

Armitage, D. R., R. Plummer, F. Berkes, R. I. Arthur, A. T. Charles, I. J. Davidson-Hunt, A. P. Diduck, N. C. Doubleday, D. S. Johnson, M. Marschke, P. McConney, E. W. Pinkerton, and E. K. Wollenberg. 2009. Adaptive co-management for socialecological complexity. Frontiers in Ecology and the Environment 7(2):95-102. http://dx.doi.org/10.1890/070089

Ban, N. C., L. S. Evans, M. Nenadovic, and M. Schoon. 2015. Interplay of multiple goods, ecosystem services, and property rights in large social-ecological marine protected areas. Ecology and Society 20(4):2. http://dx.doi.org/10.5751/ES-07857-200402

Basurto, X., S. Gelcich, and E. Ostrom. 2013. The socialecological system framework as a knowledge classificatory system for benthic small-scale fisheries. Global Environmental Change 23 (6):1366-1380. http://dx.doi.org/10.1016/j.gloenvcha.2013.08.001

Basurto, X., and M. Nenadovic. 2012. A systematic approach to studying fisheries governance. Global Policy 3(2):222-230. http:// dx.doi.org/10.1111/j.1758-5899.2011.00094.x

Béné, C., and A. Neiland. 2004. Empowerment reform, yes . . . but empowerment of whom? Fisheries decentralization reforms in developing countries: a critical assessment with specific reference to poverty reduction. Aquatic Resources, Culture and Development 1(1):35-49. http://dx.doi.org/10.1079/ARC20047

Bennett, A., and X. Basurto. 2018. Local institutional responses to global market pressures: the sea cucumber trade in Yucatán, Mexico. World Development 102:57-70. http://dx.doi.org/10.1016/ j.worlddev.2017.09.006

Bennett, N. J. 2016. Using perceptions as evidence to improve conservation and environmental management. Conservation Biology 30(3):582-592. http://dx.doi.org/10.1111/cobi.12681

Bennett, N. J., and P. Dearden. 2014. From measuring outcomes to providing inputs: governance, management, and local development for more effective marine protected areas. Marine Policy 50:96-110. http://dx.doi.org/10.1016/j.marpol.2014.05.005

Bennett, N. J., R. Roth, S. C. Klain, K. Chan, P. Christie, D. A. Clark, G. Cullman, D. Curran, T. J. Durbin, G. Epstein, A. Greenberg, M. P. Nelson, J. Sandlos, R. Stedman, T. L. Teel, R. Thomas, D. Veríssimo, and C. Wyborn. 2017. Conservation social science: understanding and integrating human dimensions to improve conservation. Biological Conservation 205:93-108. http:// dx.doi.org/10.1016/j.biocon.2016.10.006

Bentes, B., V. J. Isaac, R. V. do Espírito-Santo, T. Frédou, M. C. de Almeida, K. R. M. Mourão, and F. L. Frédou. 2012. Multidisciplinary approach to identification of fishery production systems on the northern coast of Brazil. Biota Neotropica 12(1):81-92. http://dx.doi.org/10.1590/

$\underline{\text { S1676-06032012000100006 }}$ 
Berkes, F., T. P. Hughes, R. S. Steneck, J. A. Wilson, D. R. Bellwood, B. Crona, C. Folke, L. H. Gunderson, H. M. Leslie, J. Norberg, M. Nyström, P. Olsson, H. Österblom, M. Scheffer, and B. Worm. 2006. Globalization, roving bandits, and marine resources. Science 311(5767):1557-1558. http://dx.doi.org/10.1126/ science. 1122804

Bodin, Ö. 2017. Collaborative environmental governance: achieving collective action in social-ecological systems. Science 357(6352):eaan1114. http://dx.doi.org/10.1126/science.aan1114

Boonstra, W. J., E. Björkvik, L. J. Haider, and V. Masterson. 2016. Human responses to social-ecological traps. Sustainability Science 11:877-889. http://dx.doi.org/10.1007/s11625-016-0397$\underline{\mathrm{x}}$

Borges, R., A. C. Ferreira, and L. D. Lacerda. 2017. Systematic planning and ecosystem-based management as strategies to reconcile mangrove conservation with resource use. Frontiers in Marine Science 4:1-13. http://dx.doi.org/10.3389/fmars. 2017.00353

Brewer, J. F. 2012. Don't fence me in: boundaries, policy, and deliberation in Maine's lobster commons. Annals of the Association of American Geographers 102(2):383-402. http://dx. doi.org/10.1080/00045608.2011.641889

Bryman, A. 2012. Social research methods. Fourth edition. Oxford University Press, Oxford, UK.

Carlsson, L., and F. Berkes. 2005. Co-management: concepts and methodological implications. Journal of Environmental Management 75(1):65-76. http://dx.doi.org/10.1016/j.jenvman.2004.11.008

Chico Mendes Institute for Biodiversity Conservation (ICMBio). 2012. Reserve management plan extractive marine reserve CAETÉTaperaçu (PA). Chico Mendes Institute for Biodiverstiy Conservation, Bragança, Brazil.

Cox, M. 2011. Advancing the diagnostic analysis of environmental problems. International Journal of the Commons 5 (2):346-363. http://dx.doi.org/10.18352/ijc. 273

Cox, M. 2015. A basic guide for empirical environmental social science. Ecology and Society 20(1):63. http://dx.doi.org/10.5751/ ES-07400-200163

da Rocha, D. F., M. F. Porto, T. Pacheco, and J. P. Leroy. 2017. The map of conflicts related to environmental injustice and health in Brazil. Sustainability Science 13:709-719. http://dx.doi. org/10.1007/s11625-017-0494-5

da Silva, P. P. 2004. From common property to co-management: lessons from Brazil's first maritime extractive reserve. Marine Policy 28(5):419-428. http://dx.doi.org/10.1016/j.marpol.2003.10.017

DeCaro, D. A., C. A. (T.) Arnold, E. F. Boamah, and A. S. Garmestani. 2017. Understanding and applying principles of social cognition and decision making in adaptive environmental governance. Ecology and Society 22(1):33. http://dx.doi. org/10.5751/ES-09154-220133

Di Ciommo, R. C. 2007. Gender, tourism, and participatory appraisals at the Corumbau Marine Extractive Reserve, Brazil. Human Ecology Review 14(1):56-67.

Diegues, A. C. 2008. Marine protected areas and artisanal fisheries in Brazil. International Collective in Support of Fishworkers,
Chennai, India. [online] URL: http://citeseerx.ist.psu.edu/ viewdoc/download?doi=10.1.1.547.9834\&rep=rep1\&type $=$ pdf

Diele, K., A. R. R. Araújo, M. Glaser, and U. Salzmann. 2010. Artisanal fishery of the mangrove crab Ucides cordatus (Ocypodidae) and first steps towards a successful co-management in Bragança, North Brazil. Pages 287-298 in U. Saint-Paul and H. Schneider, editors. Mangrove dynamics and management in North Brazil. Springer, Berlin, Germany. https://doi. org/10.1007/978-3-642-13457-9 19

Diele, K., and V. Koch. 2010. Comparative population dynamics and life histories of North Brazilian mangrove crabs, genera $U c a$ and Ucides (Ocypodoidea). Pages 275-285 in U. Saint-Paul and $\mathrm{H}$. Schneider, editors. Mangrove dynamics and management in North Brazil. Springer, Berlin, Germany. http://dx.doi. org/10.1007/978-3-642-13457-9_18

di Paolo, D. F. 2017. Cajueiro: agroextrativismo e relações sociais de gênero em contexto socioambiental na Amazonia paraense. Dissertation. Universidade Federal do Pará, Belém, Brazil.

Epstein, G., M. Nenadovic, and A. Boustany. 2014. Into the deep blue sea: commons theory and international governance of Atlantic bluefin tuna. International Journal of the Commons 8 (2):277-303. http://dx.doi.org/10.18352/ijc.410

Epstein, G., J. Pittman, S. M. Alexander, S. Berdej, T. Dyck, U. Kreitmair, K. J. Rathwell, S. Villamayor-Tomas, J. Vogt, and D. Armitage. 2015. Institutional fit and the sustainability of socialecological systems. Current Opinion in Environmental Sustainability 14:34-40. http://dx.doi.org/10.1016/j.cosust.2015.03.005

Eriksson, H., H. Österblom, B. Crona, M. Troell, N. Andrew, J. Wilen, and C. Folke. 2015. Contagious exploitation of marine resources. Frontiers in Ecology and the Environment 13:435-440. http://dx.doi.org/10.1890/140312

Erler, D. M., D. P. Lima, Jr., and A. Schiavetti. 2015. Ecological fishing networks in a marine protected area: one possibility for evaluating objectives. Ocean and Coastal Management 104:106-114. http://dx.doi.org/10.1016/j.ocecoaman.2014.12.008

Ernst, B., J. Chamorro, P. Manríquez, J. M. L. Orensanz, A. M. Parma, J. Porobic, and C. Román. 2013. Sustainability of the Juan Fernández lobster fishery (Chile) and the perils of generic sciencebased prescriptions. Global Environmental Change 23 (6):1381-1392 . http://dx.doi.org/10.1016/j.gloenvcha.2013.08.002

Esterci, N. 2002. Conflitos ambientais e processos classificatórios na Amazonia brasileira. Boletim Rede Amazonia: Diversidade Sociocultural e Politicas Ambientais 1(1).

Ferrol-Schulte, D., S. C. A. Ferse, and M. Glaser. 2014. Patronclient relationships, livelihoods and natural resource management in tropical coastal communities. Ocean and Coastal Management 100:63-73. http://dx.doi.org/10.1016/j.ocecoaman.2014.07.016

Flick, U. 2014. An introduction to qualitative research. Fourth edition. Sage, Thousand Oaks, California, USA.

Folke, C., T. Hahn, P. Olsson, and J. Norberg. 2005. Adaptive governance of social-ecological systems. Annual Review of Environment and Resources 30(1):441-473. http://dx.doi. org/10.1146/annurev.energy.30.050504.144511 
Frey, U. J., and M. Cox. 2015. Building a diagnostic ontology of social-ecological systems. International Journal of the Commons 9(2):595-618. http://dx.doi.org/10.18352/ijc.505

Fusch, P. I., and L. R. Ness. 2015. Are we there yet? Data saturation in qualitative research. Qualitative Report 20 (9):1408-1416. [online] URL: https://nsuworks.nova.edu/cgi/ viewcontent. . gi? article $=2281 \&$ context $=$ tqr

Glaser, M., W. Baitoningsih, S. C. A. Ferse, M. Neil, and R. Deswandi. 2010a. Whose sustainability? Top-down participation and emergent rules in marine protected area management in Indonesia. Marine Policy 34(6):1215-1225. http://dx.doi. org/10.1016/j.marpol.2010.04.006

Glaser, M., U. Berger, and R. Macedo. 2003. Local vulnerability as an advantage: mangrove forest management in Pará state, North Brazil under conditions of illegality. Regional Environmental Change 3(4):162-172. http://dx.doi.org/10.1007/ s10113-003-0057-4

Glaser, M., A. Breckwoldt, R. Deswandi, I. Radjawali, W. Baitoningsih, and S. C. A. Ferse. 2015. Of exploited reefs and fishers - a holistic view on participatory coastal and marine management in an Indonesian archipelago. Ocean and Coastal Management 116:193-213. http://dx.doi.org/10.1016/j. ocecoaman.2015.07.022

Glaser, M., and R. Da Silva Oliveira. 2004. The prospects for comanagement of mangrove ecosystems on the North Brazilian coast - whose rights, whose duties and whose priorities? Natural Resources Forum 28:224-233. http://dx.doi.org/10.1111/ j.1477-8947.2004.00092.x

Glaser, M., P. Christie, K. Diele, L. Dsikowitzky, S. Ferse, I. Nordhaus, A. Schlüter, K. Schwerdtner Mañez, and C. Wild. 2012. Measuring and understanding sustainability-enhancing processes in tropical coastal and marine social-ecological systems. Current Opinion in Environmental Sustainability 4(3):300-308. http://dx.doi.org/10.1016/j.cosust.2012.05.004

Glaser, M., and K. Diele. 2004. Asymmetric outcomes: assessing the biological, economic and social sustainability of a mangrove crab fishery, Ucides cordatus (Ocypodidae), in North Brazil. Ecological Economics 49(3):361-373. http://dx.doi.org/10.1016/j. ecolecon.2004.01.017

Glaser, M., and B. Glaeser. 2012. The social dimension in the management of social-ecological change. Pages 5-30 in $\mathrm{H}$. Kremer and J. Pinckney, editors. Integrated Management of Estuaries and Coasts. Elsevier, Munich, Germany.

Glaser, M., G. Krause, R. S. Oliveira, and M. Herazo-Fontalvo. $2010 b$. Mangroves and people: a social-ecological system. Pages 307-351 in U. Saint-Paul and H. Schneider, editors. Mangrove dynamics and management in North Brazil. Springer, Berlin, Germany. https://doi.org/10.1007/978-3-642-13457-9 21

Halpern, B. S. 2014. Making marine protected areas work. Nature 506:167-168. http://dx.doi.org/10.1038/nature13053

Hinkel, J., M. E. Cox, M. Schlüter, C. R. Binder, and T. Falk. 2015. A diagnostic procedure for applying the social-ecological systems framework in diverse cases. Ecology and Society 20(1):32. http://dx.doi.org/10.5751/ES-07023-200132
Hoogesteger, J. 2015. Normative structures, collaboration and conflict in irrigation; a case study of the Píllaro North Canal Irrigation System, Ecuadorian Highlands. International Journal of the Commons 9(1):398-415. http://dx.doi.org/10.18352/ijc.521

Institute of the Environment and Renewable Natural Resources (IBAMA). 2005. Instrução normativa. No. 66, de 12 de Maio de 2005. Institute of the Environment and Renewable Natural Resources (IBAMA), Brasilia, Brazil. [online] URL: http://www. ibama.gov.br/sophia/cnia/legislacao/IBAMA/IN0066-120505.PDF

Institute of the Environment and Renewable Natural Resources (IBAMA). 2013a. Instrução normativa. No. 09 de 22 de maio de 2013. Institute of the Environment and Renewable Natural Resources (IBAMA), Brasilia, Brazil. [online] URL: http://www. icmbio.gov.br/cepsul/images/stories/legislacao/Instrucao_normativa/2013/ in_ibama_09_2013_revoga_in_ibama_66_2013 agentesambientaisvoluntarios.pdf

Jentoft, S. 2000. Legitimacy and disappointment in fisheries management. Marine Policy 24(2):141-148. http://dx.doi. org/10.1016/S0308-597X(99)00025-1

Jones, P. J. S., W. Qiu, and E. M. De Santo. 2013. Governing marine protected areas: social-ecological resilience through institutional diversity. Marine Policy 41:5-13. http://dx.doi. org/10.1016/j.marpol.2012.12.026

Kasanoski, D. S. 2016. Bolsa verde: beneficio social e incentivo à conservação ambiental? Thesis. Universidade de Brasília, Brasília, Brazil. [online] URL: http://repositorio.unb.br/handle/10482/23376? mode $=$ full

Koch, V., and I. Nordhaus. 2010. Feeding ecology and ecological role of North Brazilian mangrove crabs. Pages 265-273 in U. SaintPaul and H. Schneider, editors. Mangrove dynamics and management in North Brazil. Springer, Berlin, Germany. http:// dx.doi.org/10.1007/978-3-642-13457-9 17

Koralagama, D., J. Gupta, and N. Pouw. 2017. Inclusive development from a gender perspective in small scale fisheries. Current Opinion in Environmental Sustainability 24:1-6. http://dx. doi.org/10.1016/j.cosust.2016.09.002

Krauss, K. W., K. L. McKee, C. E. Lovelock, D. R. Cahoon, N. Saintilan, R. Reef, and L. Chen. 2014. How mangrove forests adjust to rising sea level. New Phytologist 202(1):19-34. http://dx. doi.org/10.1111/nph.12605

Lara, R. J., M. Cohen, and C. Szlafsztein. 2010. Drivers of temporal changes in mangrove vegetation boundaries and consequences for land use. Pages 127-142 in U. Saint-Paul and H. Schneider, editors. Mangrove dynamics and management in North Brazil. Springer, Berlin, Germany. http://dx.doi.org/10.1007/978$\underline{-3-642-13457-98}$

Legat, J. F. A., A. P. Legat, A. L. M. Pereira, J. M. de Góes, and L. C. F. Góes. 2006. Caranguejo-uçá: métodos para captura, estocagem e transporte. Embrapa Meio-Norte-Documentos (INFOTECA-E). Ministeria de Agricultura, Pecuaria e Abastecimento, Tersina, Brazil.

Leslie, H. M., X. Basurto, M. Nenadovic, L. Sievanen, K. C. Cavanaugh, J. J. Cota-Nieto, B. E. Erismang, E. Finkbeiner, G. Hinojosa-Arango, M. Moreno-Báez, S. Nagavarapu, S. M. W. 
Reddy, A. Sánchez-Rodríguez, K. Siegel, J. J. UlibarriaValenzuela, A. H. Weaver, and O. Aburto-Oropeza. 2015. Operationalizing the social-ecological systems framework to assess sustainability. Proceedings of the National Academy of Sciences 112(19):5979-5984. http://dx.doi.org/10.1073/pnas.1414640112

Le Tourneau, F.-M., and B. Beaufort. 2017. Exploring the boundaries between individual and collective land use management in a CPR system: the PAE Chico Mendes (Acre, Brazil). International Journal of the Commons 11(1):70-96. http:// dx.doi.org/10.18352/ijc.589

London, S., M. L. Rojas, M. M. I. Martin, F. Scordo, M. A. H. Cisneros, M. L. Bustos, G. M. E. Perillo, and M. C. Piccolo. 2017. Characterization of an artisanal fishery in Argentina using the social-ecological systems framework. International Journal of the Commons 11(1):.1-69. http://dx.doi.org/10.18352/ijc.534

López-Angarita, J., R. Moreno-Sánchez, J. H. Maldonado, and J. A. Sánchez. 2014. Evaluating linked social-ecological systems in marine protected areas. Conservation Letters 7(3):241-252. http://dx.doi.org/10.1111/conl.12063

Lozano, A. J. G., and J. T. Heinen. 2016. Identifying drivers of collective action for the co-management of coastal marine fisheries in the Gulf of Nicoya, Costa Rica. Environmental Management 57:759-769.

Mace, G. M. 2014. Whose conservation? Science 345 (6204):1558-1560. http://dx.doi.org/10.1126/science.1254704

McGinnis, M. D., and E. Ostrom. 2014. Social-ecological system framework: initial changes and continuing challenges. Ecology and Society 19(2):30. http://dx.doi.org/10.5751/ES-06387-190230

Ministério da Agricultura, Pecuária e Abastecimento (MAPA). 2017. Instrução normativa interministerial. No. 06, de 16 de janeiro de 2017. Minist Ã@rio da Agricultura, PecuÃ Abastecimento, Brasilia, Brazil. [online] URL: http://www. editoramagister.com/legis 27281932 INSTRUCAO NORMATIVA_INTERMINISTERIAL_N_6_DE_16_DE_JANEIRO_DE_2017. $\underline{\operatorname{aspx}}$

Ministério da Pesca e Aquicultura (MPA). 2013. Instrução normativa. No. 09 de 02 de julho de 2013. Ministério da Pesca e Aquicultura, Brasilia, Brazil. [online] URL: http://www.adepara. pa.gov.br/sites/default/files/in mpa 092013 normas transporte_caranguejo-uca_pa_ma_pi_ce.pdf

Narahara, K. L. 2014. Para evitar questão: a elaboração do plano de utilização em uma reserva extrativista. in N. Esterci, H. O. Sant'ana-Júnior, and M. J. S. A. Teisserenc, editors. Territórios socioambientais em construção na Amazônia brasileira. HIFE (Sociologia and Antropologia), Rio de Janeiro, Brazil.

Nascimento, J. R., D. Domingues, and R. S. L. Barboza. 2015. A cadeia produtiva do caranguejo (Ucides cordatus): os desafios frente às pressões do mercado no território da Resex Marinha Caeté-Taperaçu, Bragança-Pará. Revista Saude e Ciencia 4 (2):299-309.

Nenadovic, M., and G. Epstein. 2016. The relationship of social capital and fishers' participation in multi-level governance arrangements. Environmental Science and Policy 61:77-86. http:// dx.doi.org/10.1016/j.envsci.2016.03.023
Noble, B. F. 2000. Institutional criteria for co-management. Marine Policy 24(1):69-77. http://dx.doi.org/10.1016/S0308-597X (99)00014-7

Nobre, D. M., D. T. Alarcon, A. Cinti, and A. Schiavetti. 2017. Governance of the Cassurubá Extractive Reserve, Bahia State, Brazil: an analysis of strengths and weaknesses to inform policy. Marine Policy 77:44-55. http://dx.doi.org/10.1016/j.marpol.2016.12.008

Oliveira, M. D. V., and M. C. A. Maneschy. 2014. Territories and territorialities on the extraction of crabs in Pontinha de Bacuriteua, Bragança, Pará. Boletim do Museu Paraense Emílio Goeldi. Ciências Humanas 9(1):129-143. http://dx.doi.org/10.1590/ $\underline{\mathrm{S} 1981-81222014000100009}$

Olsson, P., C. Folke, V. Galaz, T. Hahn, and L. Schultz. 2007. Enhancing the fit through adaptive co-management: creating and maintaining bridging functions for matching scales in the Kristianstads Vattenrike Biosphere Reserve, Sweden. Ecology and Society 12(1):28. http://dx.doi.org/10.5751/ES-01976-120128

Ostrom, E. 1990. Governing the commons: the evolution of institutions for collective action. Cambridge University Press, Cambridge, UK. [online] URL: http://wtf.tw/ref/ostrom_1990. pdf

Ostrom, E. 2007. A diagnostic approach for going beyond panaceas. Proceedings of the National Academy of Sciences 104 (39):15181-15187. http://dx.doi.org/10.1073/pnas.0702288104

Ostrom, E. 2009. A general framework for analyzing sustainability of social-ecological systems. Science 325 (5939):419-422. http://dx.doi.org/10.1126/science.1172133

Ostrom, E., and M. Cox. 2010. Moving beyond panaceas: a multitiered diagnostic approach for social-ecological analysis. Environmental Conservation 37(4):451-463. http://dx.doi.org/10.1017/ $\underline{\mathrm{S} 0376892910000834}$

Partelow, S. 2015. Key steps for operationalizing social-ecological system framework research in small-scale fisheries: a heuristic conceptual approach. Marine Policy 51:507-511. http://dx.doi. org/10.1016/j.marpol.2014.09.005

Partelow, S. 2016. Coevolving Ostrom's social-ecological systems (SES) framework and sustainability science: four key co-benefits. Sustainability Science 11(3):399-410. http://dx.doi.org/10.1007/ $\underline{\text { s11625-015-0351-3 }}$

Partelow, S., and C. Boda. 2015. A modified diagnostic socialecological system framework for lobster fisheries: case implementation and sustainability assessment in Southern California. Ocean and Coastal Management 114:204-217. http:// dx.doi.org/10.1016/j.ocecoaman.2015.06.022

Partelow, S., A. Schlüter, H. von Wehrden, M. Jänig, and P. Senff. 2018a. A sustainability agenda for tropical marine science. Conservation Letters 11(1):e12351. http://dx.doi.org/10.1111/ conl.12351

Partelow, S., P. Senff, N. Buhari, and A. Schlüter. $2018 b$. Operationalizing the social-ecological systems framework in pond aquaculture. International Journal of the Commons 12 (1):485-518. http://dx.doi.org/10.18352/ijc.834 
Partelow, S., and K. J. Winkler. 2016. Interlinking ecosystem services and Ostrom's framework through orientation in sustainability research. Ecology and Society 21(3):27. http://dx. doi.org/10.5751/ES-08524-210327

Pinheiro, H. T., F. Di Dario, L. C. Gerhardinger, M. R. S. de Melo, R. L. de Moura, R. E. Reis, F. Vieira, J. Zuanon, and L. A. Rocha. 2015. Brazilian aquatic biodiversity in peril. Science 350 (6264):1043-1044. http://dx.doi.org/10.1126/science.350.6264.1043a

Pittman, J., and D. Armitage. 2016. Governance across the landsea interface: a systematic review. Environmental Science and Policy 64:9-17. http://dx.doi.org/10.1016/j.envsci.2016.05.022

Plummer, R., and A. Hashimoto. 2011. Adaptive co-management and the need for situated thinking in collaborative conservation. Human Dimensions of Wildlife 16(4):222-235. http://dx.doi. org/10.1080/10871209.2011.585434

Pollnac, R., P. Christie, J. E. Cinner, T. Dalton, T. M. Daw, G. E. Forrester, N. A. J. Graham, and T. R. McClanahan. 2010. Marine reserves as linked social-ecological systems. Proceedings of the National Academy of Sciences 107(43):18262-18265. http://dx. doi.org/10.1073/pnas.0908266107

Pomeroy, R. S., L. M. Watson, J. E. Parks, and G. A. Cid. 2005. How is your MPA doing? A methodology for evaluating the management effectiveness of marine protected areas. Ocean and Coastal Management 48(7-8):485-502. http://dx.doi.org/10.1016/ j.ocecoaman.2005.05.004

Poteete, A., M. A. Janssen, and E. Ostrom. 2010. Working together: collective action, the commons and multiple methods in practice. Princeton University Press, Princeton, New Jersey, USA. http://dx.doi.org/10.1515/9781400835157

Rahman, H. M. T., A. S. Sainte Ville, A. M. Song, J. Y. T. Po, E. Berthet, J. R. Brammer, N. D. Brunet, N. G. Jayaprakash, K. N. Lowitt, A. Rastogi, G. Reed, and G. M. Hickey. 2017. A framework for analyzing institutional gaps in natural resource governance. International Journal of the Commons 11(2):823-853. http://dx.doi.org/10.18352/ijc.758

Reed, M. S., A. C. Evely, G. Cundill, I. Fazey, J. Glass, A. Laing, J. Newig, B. Parrish, C. Prell, C. Raymond, and L. C. Stringer. 2010. What is social learning? Ecology and Society 15(4):r1. http:// dx.doi.org/10.5751/ES-03564-1504r01

Ruitenbeek, J., and C. Cartier. 2001. The invisible wand: adaptive co-management as an emergent strategy in complex bio-economic system. CIFOR, Bogor, Indonesia. [online] URL: http://www. cifor.org/publications/pdf files/OccPapers/OP-034.pdf

Saint-Paul, U., and H. Schneider. 2010. Mangrove dynamics and management in North Brazil. Springer, Berlin, Germany. http:// dx.doi.org/10.1007/978-3-642-13457-9

Sant'ana-Júnior, H. A. 2014. Projetos de desenvolvimento e a criação de reservas extrativistas: estratégias de luta de grupos sociais locais no Acre e no Maranhão. in N. Esterci, H. A. Sant'ana-Júnior, and M. J. S. Teisserenc, editors. Territórios socioambientais em construção na Amazônia brasileira. HIFE (Sociologia and Antropologia), Rio de Janeiro, Brazil.
Santos, A. N. 2015. Fisheries as a way of life: gendered livelihoods, identities and perspectives of artisanal fisheries in eastern Brazil. Marine Policy 62:279-288. http://dx.doi.org/10.1016/j.marpol.2015.09.007

Santos, A. N., and C. Brannstrom. 2015. Livelihood strategies in a marine extractive reserve: implications for conservation interventions. Marine Policy 59:44-52. http://dx.doi.org/10.1016/ j.marpol.2015.05.004

Santos, C. Z., and A. Schiavetti. 2014. Assessment of the management in Brazilian marine extractive reserves. Ocean and Coastal Management 93:26-36. http://dx.doi.org/10.1016/j. ocecoaman.2014.03.007

Santos, C. Z., and A. Schiavetti. 2017. Reservas extrativistas marinhas do Brasil: contradições de ordem legal, sustentabilidade e aspecto ecológico. Boletim do Instituto de Pesca 39(4):479-494. [online] URL: https://www.pesca.sp.gov.br/39 4 479-494.pdf

Santos, L. C. M., M. A. Gasalla, F. Dahdouh-Guebas, and M. D. Bitencourt. 2017. Socio-ecological assessment for environmental planning in coastal fishery areas: a case study in Brazilian mangroves. Ocean and Coastal Management 138:60-69. http://dx.doi.org/10.1016/j.ocecoaman.2017.01.009

Schlager, E., and E. Ostrom. 1992. Property-rights regimes and natural resources: a conceptual analysis. Land Economics 68 (3):249-262. http://dx.doi.org/10.2307/3146375

Schlüter, A., and R. Madrigal. 2012. The SES framework in a marine setting : methodological lessons. Rationality, Markets and Morals 3:148-167.

Schlüter, A., S. Partelow, L. E. T. Guevara, and T. Jennerjahn. 2018. Coastal commons as social-ecological systems. In B. Hudson, J. Rosenbloom, and D. H. Cole, editors. Handbook of the study of the commons. Routledge, Abington, UK.

Schlüter, A., S. Wise, K. Schwerdtner-Mánez, G. W. de Morais, and M. Glaser. 2013. Institutional change, sustainability and the sea. Sustainability 5(12):5373-5390. http://dx.doi.org/10.3390/ $\underline{\text { su} 5125373}$

Silva-Junior, S. R. 2013. Participação e relações de poder no conselho deliberativo da Reserva Extrativista Marinha CaetéTaperaçu, Bragança-PA. Universidade Federal do Pará, Belém, Pará, Brazil.

Silverman, D. 2005. Doing qualitative research. Sage, Thousand Oak, California, USA.

Simonian, L. T. L., and M. Glaser. 2002. Extractive reserves and the question of sustainability in neotropical ecosystems. Pages 767-776 in Neotropical ecosystems: proceedings of the GermanBrazilian workshop. Hamburg, Germany.

Tam, C.-L. 2015. Timing exclusion and communicating time: a spatial analysis of participation failure in an Indonesian MPA Marine Policy 54:122-129. http://dx.doi.org/10.1016/j.marpol.2015.01.001

Tebet, G., M. Trimble, and R. Pereira Medeiros. 2018. Using Ostrom's principles to assess institutional dynamics of conservation: lessons from a marine protected area in Brazil. Marine Policy 88:174-181. http://dx.doi.org/10.1016/j.marpol.2017.10.037

Teisserenc, M. J. S. 2014. Atores não governamentais, relações, representações e desafios do desenvolvimento sustentável (na 
Amazônia brasileira). Pages 73-104 in N. Esterci, H. A. Sant'anaJúnior, and M. J. S. Teisserenc, editors. Territórios socioambientais em construção na Amazônia brasileira. HIFE (Sociologia \& Antropologia), Rio de Janeiro, Brazil.

Tengö, M., E. S. Brondizio, T. Elmqvist, P. Malmer, and M. Spierenburg. 2014. Connecting diverse knowledge systems for enhanced ecosystem governance: the multiple evidence base approach. Ambio 43(5):579-591. http://dx.doi.org/10.1007/ $\underline{\text { s13280-014-0501-3 }}$

Thies-Albrecht, O. 2016. Spatial and temporal dispersal of the $\mathrm{U}$. cordatus crab fishery in mangroves near Bragança, Northern Brazil: fishers as optimal foragers and resulting management applications. University of Bremen, Bremen, Germany.

Torres Guevara, L. E., A. Schlüter, and M. C. Lopez. 2016. Collective action in a tropical estuarine lagoon: adapting Ostrom's SES framework to Ciénaga Grande de Santa Marta. International Journal of the Commons 10(1):334-362. http://doi.org/10.18352/ ijc. 623

Vadjunec, J. M., and D. Rocheleau. 2009. Beyond forest cover: land use and biodiversity in rubber trail forests of the Chico Mendes Extractive Reserve. Ecology and Society 14(2):29. http:// dx.doi.org/10.5751/ES-03010-140229

VERBI Software. 2016. MaxQDA. VERBI Software, Berlin, Germany.

Weber de Morais, G., A. Schlüter, and M. Verweij. 2015. Can institutional change theories contribute to the understanding of marine protected areas? Global Environmental Change 31:154-162. http://dx.doi.org/10.1016/j.gloenvcha.2015.01.008

Whitney, C. K., N. J. Bennett, N. C. Ban, E. H. Allison, D. Armitage, J. L. Blythe, J. M. Burt, W. Cheung, E. M. Finkbeiner, M. Kaplan-Hallam, I. Perry, N. J. Turner, and L. Yumagulova. 2017. Adaptive capacity: from assessment to action in coastal social-ecological systems. Ecology and Society 22(2):22. http://dx. doi.org/10.5751/ES-09325-220222

Woodroffe, C. D., K. Rogers, K. L. McKee, C. E. Lovelock, I. A. Mendelssohn, and N. Saintilan. 2016. Mangrove sedimentation and response to relative sea-level rise. Annual Review of Marine Science 8(1):243-266. http://dx.doi.org/10.1146/annurevmarine-122414-034025

Zurba, M., and M. Trimble. 2014. Youth as the inheritors of collaboration: crises and factors that influence participation of the next generation in natural resource management. Environmental Science and Policy 42:78-87. http://dx.doi. org/10.1016/j.envsci.2014.05.009 


\section{Appendix 1}

Table A1.1 The SES framework with second-tier variables alternative structure for Governance Systems (GS) proposed by McGinnis \& Ostrom (2014) in table format. Followed by the visualization of the conceptual interactions between first-tier variables (McGinnis \& Ostrom, 2014).

\begin{tabular}{|c|c|}
\hline \multicolumn{2}{|c|}{$\begin{array}{l}\text { Social, Economic, and Political Settings (S) } \\
\text { S1- Economic development. S2- Demographic trends. S3- Political stability. } \\
\text { S4- Other governance systems. S5- Markets. S6- Media organizations. S7- Technology. }\end{array}$} \\
\hline $\begin{array}{l}\qquad \text { Resource Systems (RS) } \\
\text { RS1- Sector (e.g., water, forests, pasture) } \\
\text { RS2- Clarity of system boundaries } \\
\text { RS3- Size of resource system } \\
\text { RS4- Human-constructed facilities } \\
\text { RS5- Productivity of system } \\
\text { RS6- Equilibrium properties } \\
\text { RS7- Predictability of system dynamics } \\
\text { RS8- Storage characteristics } \\
\text { RS9- Location }\end{array}$ & $\begin{array}{l}\text { Governance Systems (GS) } \\
\text { GS1- Policy area } \\
\text { GS2- Geographic scale of governance } \\
\text { GS3- Population } \\
\text { GS4- Regime type } \\
\text { GS5- Rule-making organizations } \\
\text { GS5.1- Public sector } \\
\text { GS5.2- Private sector (for profit) } \\
\text { GS5.3- Non-governmental (non-profit) } \\
\text { GS5.4- Community-based } \\
\text { GS5.5- Hybrid } \\
\text { GS6- Rules-in-use } \\
\text { GS6.1- Operational choice rules } \\
\text { GS6.2- Collective choice rules } \\
\text { GS6.3- Constitutional rules } \\
\text { GS7- Property-rights systems } \\
\text { GS8- Repertoire of norms and strategies } \\
\text { GS9- Network structure } \\
\text { GS10- Historical continuity }\end{array}$ \\
\hline $\begin{array}{l}\text { Resource Units (RU) } \\
\text { RU1- Resource unit mobility } \\
\text { RU2- Growth or replacement rate } \\
\text { RU3- Interaction among resource units } \\
\text { RU4- Economic value } \\
\text { RU5- Number of units } \\
\text { RU6- Distinctive characteristics } \\
\text { RU7- Spatial and temporal distribution }\end{array}$ & 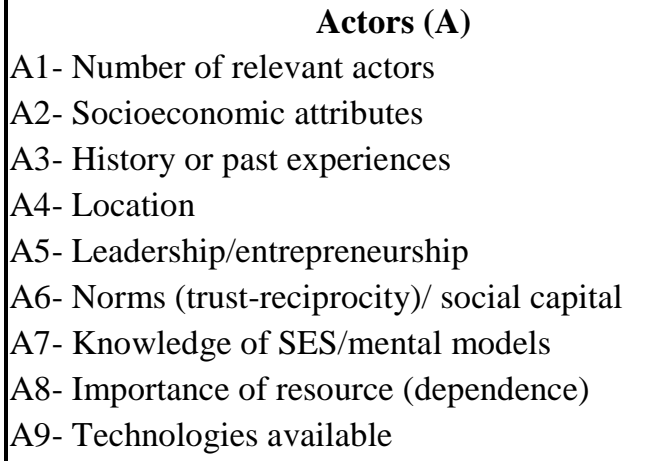 \\
\hline $\begin{array}{l}\text { Interactions (I) } \\
\text { I1- Harvesting } \\
\text { I2- Information sharing } \\
\text { I3- Deliberation processes } \\
\text { I4- Conflicts } \\
\text { I5- Investment activities } \\
\text { I6- Lobbying activities } \\
\text { I7- Self-organizing activities } \\
\text { I8- Networking activities } \\
\text { I9- Monitoring activities } \\
\text { I10- Evaluative activities }\end{array}$ & $\begin{array}{l}\text { Outcomes }(\mathbf{O}) \\
\text { O1- Social performance measures } \\
\text { O2- Ecological performance measures } \\
\text { O3- Externalities to other SESs }\end{array}$ \\
\hline ECO1 Climate patterns EC & $\begin{array}{l}\text { ystems (ECO) } \\
\text { patterns ECO3- Flows into and out of SES }\end{array}$ \\
\hline
\end{tabular}


Figure A1.1 The SES framework first-tier variables in visual form (McGinnis \& Ostrom, 2014).

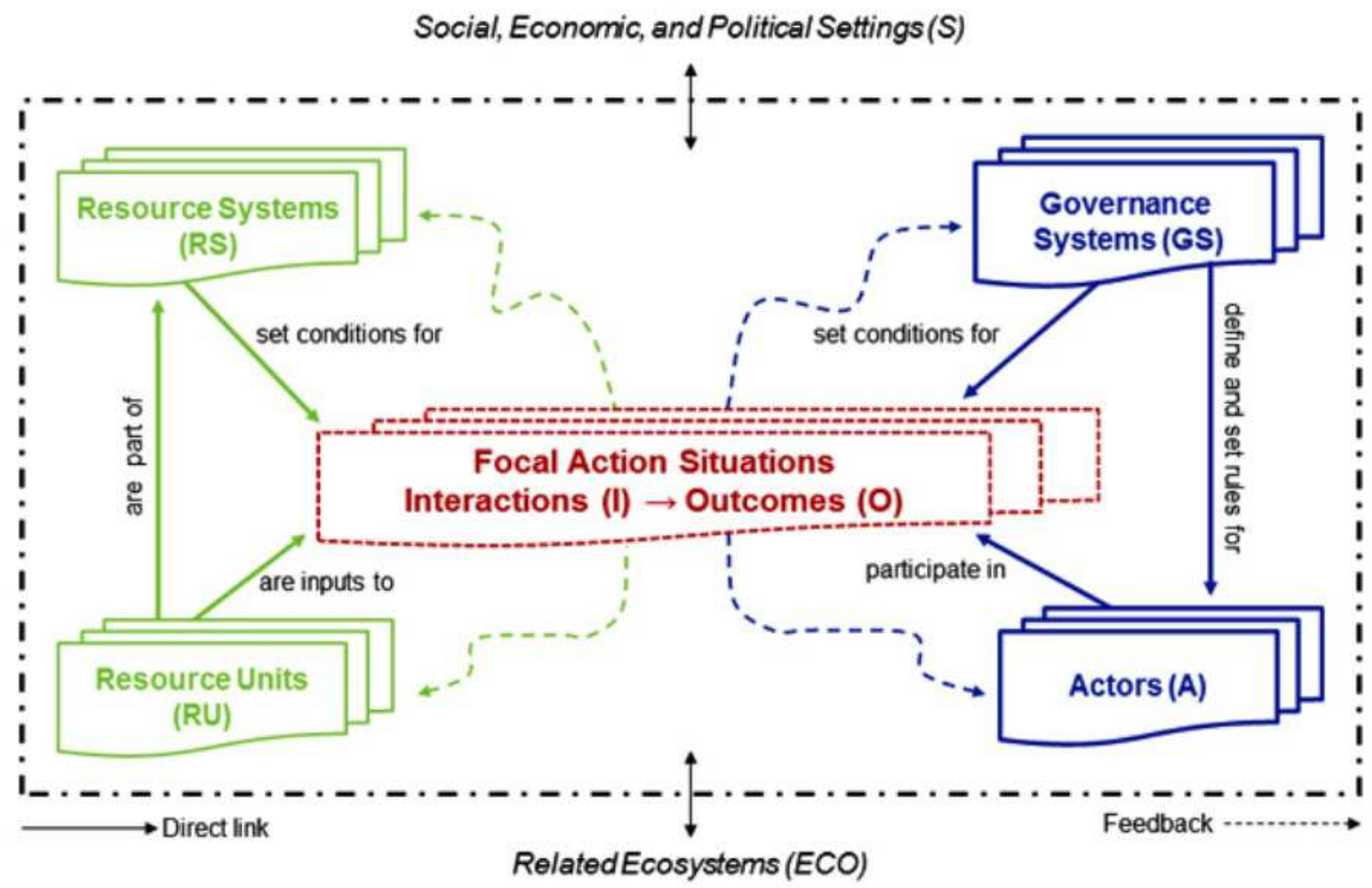

McGinnis, M.D., and E. Ostrom. 2014. Social-Ecological System Framework: Initial Changes and Continuing Challenges. Ecology and Society 19 (2). https://doi.org/10.5751/ES-06387-190230 
Appendix 2. Timeline of key events.

\begin{tabular}{|c|c|}
\hline Date & Event \\
\hline 1990 & First RESEX created in Brazil \\
\hline 1960 to 90 's & $\begin{array}{l}\text { Drought related immigration waves from the State of Ceará to Bragança, and from the logged } \\
\text { and cattle farmed Amazonian rainforests, both expanding the fishing sector. }\end{array}$ \\
\hline Late 1990 's & First social movements advocating for RESEX establishment in Braganca. \\
\hline 1995 & $\begin{array}{l}\text { "Mangrove Dynamics and Management" (MADAM) research program was initiated to research } \\
\text { the dynamics of mangrove ecosystems and to support the formulation of management } \\
\text { recommendations based on this knowledge. }\end{array}$ \\
\hline 2000 & First concerted initiative at RESEX creation in Braganca with required preliminary studies. \\
\hline May 2005 & Creation of the Caeté-Taperaçú RESEX. “Plano de Utilização". \\
\hline August 2005 & Association of RESEX Users (ASSUREMACATA) is established. \\
\hline 2006 & $\begin{array}{l}\text { Benefits come to RESEX members (houses, scholarships, compensation payments for foregone } \\
\text { use of nature, consumer goods such as refrigerators, cookers). }\end{array}$ \\
\hline 2007 & Constitution for the RESEX Deliberative Council established. \\
\hline 2008 & $\begin{array}{l}\text { Dispute between community leaders for the institutional political space in RESEX management } \\
\text { (legislative election- "vereador"). }\end{array}$ \\
\hline \multirow[t]{4}{*}{2009} & Chico Mendes Institute for Biodiversity Conservation (ICMBio) established. \\
\hline & Arrival of the first manager of the RESEX \\
\hline & Start of process to develop management plan. \\
\hline & $\begin{array}{l}\text { The meeting "I Forum paraense do caranguejo-uça" with } 500 \text { crab collectors representing } 21 \\
\text { municipalities from State of Pará discussed the crab fishery management. }\end{array}$ \\
\hline \multirow[t]{2}{*}{2011} & $\begin{array}{l}\text { The "Contrato de Concessão de Direito Real de Uso" (Land concession to the associaiton of } \\
\text { users) of the RESEX was established for } 50 \text { years }\end{array}$ \\
\hline & Publication of who is eligible to receive benefits from governmental programs in the CT RESEX, \\
\hline
\end{tabular}




\begin{tabular}{|c|c|}
\hline & decided by the Deliberative Council. \\
\hline 2012 & Publication of Management plan for the Caeté-Taperaçú RESEX. \\
\hline 2013 & Judicial suspension of user association (ASSUREMACATA) \\
\hline \multirow[t]{2}{*}{2014} & $\begin{array}{l}\text { IDATAM (Institute of Development and Technical Assistance of the Amazon), civil association } \\
\text { that provided services of technical assistance and rural extension to RESEX communities. }\end{array}$ \\
\hline & $\begin{array}{l}\text { Creation of CONFREM (“Comissão Nacional para o Fortalecimento das Reservas Extrativistas e } \\
\text { dos Povos Extrativistas Costeiros Marinhos"): Representation of Traditional Populations from } \\
\text { marine RESEX areas. }\end{array}$ \\
\hline \multirow[t]{2}{*}{2015} & Evaluation workshop with 40 communities represented. \\
\hline & $\begin{array}{l}\text { Meetings to update the operational use rules of the RESEX (Work Groups: crab, fisheries, } \\
\text { currals and monitoring). "Acordos de Gestão" (Updating of "Plano de Utilização") }\end{array}$ \\
\hline \multirow[t]{2}{*}{2017} & $\begin{array}{l}\text { Training of young people in sustainability by UNESCO Cooperation Program and Vale } \\
\text { Foundation (Sustainable Fishing Project on the Amazon Coast - "PeSCA") }\end{array}$ \\
\hline & $\begin{array}{l}\text { Training program for leadership and biological monitoring of fisheries- crab, Ucides } \\
\text { cordatus, and king weakfish, Macrodon ancylodon- was initiated by the NGO Rare (Fish } \\
\text { Forever Program). }\end{array}$ \\
\hline
\end{tabular}


Appendix 3. Rules-in-use.

\begin{tabular}{|c|c|}
\hline $\begin{array}{l}\text { Rules-in-use } \\
\text { (GS6) }\end{array}$ & Rules \\
\hline $\begin{array}{l}\text { Operational } \\
\text { rules* } \\
\text { (GS6.1) }\end{array}$ & $\begin{array}{l}\text { - } \quad \text { The RESEX is divided into six use zones: Population, Extraction, Recovery, Community } \\
\text { - } \quad \text { Reserve, Priority Conservation, Priority Sustainable Tourism } \\
\text { - } \quad \text { Access to natural resources is restricted to registered CT RESEX users } \\
\text { - } \quad \text { Fishing gear limited to traditional and small-scale techniques } \\
\text { - } \quad \text { Seasonal closure for crab reproduction, but no compensation } \\
\text { - } \quad \text { No harvesting of female crabs, minimum male crab size of } 6 \mathrm{~cm} \text { carapace } \\
\text { - } \quad \text { Enforcement should include community participation } \\
\text { - } \quad \text { Basic infrastructure for harvesting can be built (e.g., paths, roads, piers) } \\
\text { - } \quad \text { Tax paid by registered users to Deliberative Council } \\
\text { - } \quad \text { Graduated sanctions }\end{array}$ \\
\hline $\begin{array}{l}\text { Collective } \\
\text { choice rules* } \\
\text { (GS6.2) }\end{array}$ & 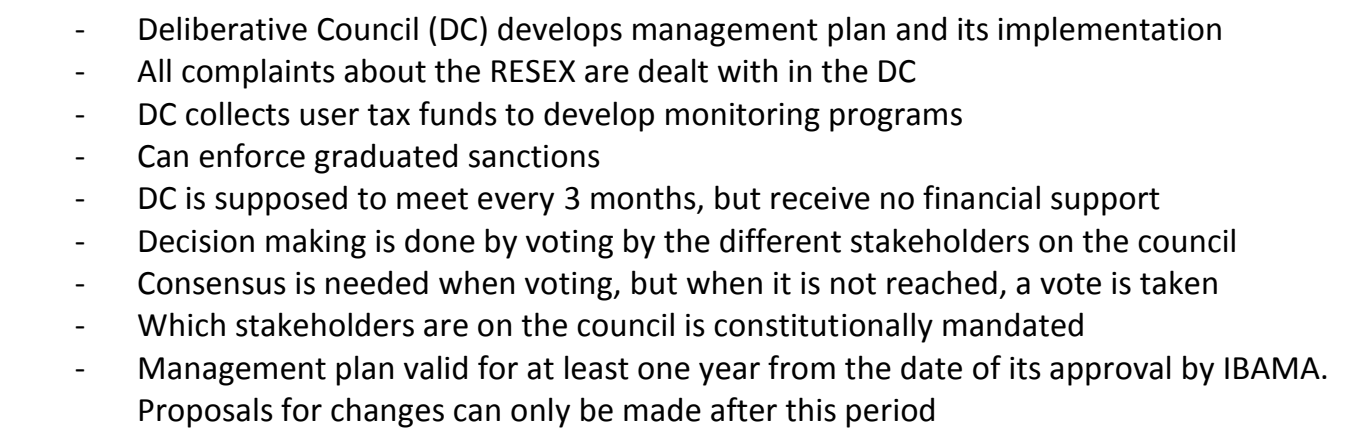 \\
\hline $\begin{array}{l}\text { Constitutional } \\
\text { rules* } \\
\text { (GS6.3) }\end{array}$ & $\begin{array}{l}\text { - } \quad \text { Formal management plan given to IBAMA to approve } \\
\text { - } \quad \text { RESEX must have a Deliberative Council with specific stakeholders involved } \\
\text { - } 50 \text { year land use concession granted to users } \\
\text { - } \quad \text { Management plan needs to be updated every } 5 \text { years } \\
\text { - } \quad \text { Any significant social or environmental intervention in the RESEX must be approved by } \\
\text { the respective supervisory agencies } \\
\text { - Changes in the rules may neither conflict with the objectives of the reserve nor with } \\
\text { current national environmental legislation }\end{array}$ \\
\hline
\end{tabular}

